\title{
A Comparative Review of Footwear-Based Wearable Systems
}

\author{
Nagaraj Hegde, Matthew Bries and Edward Sazonov * \\ Department of Electrical and Computer Engineering, The University of Alabama; Tuscaloosa, AL 35487, USA; \\ nhegde@crimson.ua.edu (N.H.); mdbries@crimson.ua.edu (M.B.) \\ * Correspondence: esazonov@eng.ua.edu; Tel.: +1-205-348-1981
}

Academic Editor: Enzo Pasquale Scilingo and Gaetano Valenza

Received: 14 July 2016; Accepted: 1 August 2016; Published: 10 August 2016

\begin{abstract}
Footwear is an integral part of daily life. Embedding sensors and electronics in footwear for various different applications started more than two decades ago. This review article summarizes the developments in the field of footwear-based wearable sensors and systems. The electronics, sensing technologies, data transmission, and data processing methodologies of such wearable systems are all principally dependent on the target application. Hence, the article describes key application scenarios utilizing footwear-based systems with critical discussion on their merits. The reviewed application scenarios include gait monitoring, plantar pressure measurement, posture and activity classification, body weight and energy expenditure estimation, biofeedback, navigation, and fall risk applications. In addition, energy harvesting from the footwear is also considered for review. The article also attempts to shed light on some of the most recent developments in the field along with the future work required to advance the field.
\end{abstract}

Keywords: accelerometry; energy expenditure; energy harvesting; footwear; gait; plantar pressure; wearable sensors

\section{Introduction}

Footwear is an irreplaceable part of human life across the globe. While the initial necessity was purely to protect the feet [1], they have also become a symbol of style and personality [2]. Footwear acts as the interface between the ground and the wearer's foot. Lots of information can be gleaned from observing this interaction. Attempts to capture this information by integrating sensing elements and electronics in the footwear began in the 1990s, both for academic research purposes and in commercial products [3]. In recent times, development of low power, wireless, unobtrusive and socially acceptable wearable computing systems has become an increasingly important research topic. This trend is aided by the exponential growth in the electronics industry, which is driving rapid advancements in microfabrication processes, wireless communication, and sensor systems.

The applications for footwear-based systems range from simple step counting solutions to more advanced systems intended for use in rehabilitation programs for disabled subjects. Footwear-based systems available on the market or in research laboratories today vary in their sensor modalities and data acquisition methodologies in order to meet different application requirements. Typically, these systems consist of pressure sensors for plantar pressure measurement, inertial sensors (accelerometer and/or gyroscope) for movement detection and a wired or wireless connection for data acquisition. The signal processing of this collected data varies depending on the application, can range from lightweight signal processing methodologies (for example, binary decision trees) running on a handheld device to complex signal processing/machine learning models (for example, Support Vector Machines) running on a PC. 
Several vital biomechanical parameters can be estimated using sensors placed in the footwear. For example, by placing pressure-sensitive elements in the footwear, foot plantar pressure can be measured. By utilizing pressure-sensitive elements along with inertial sensors, several gait parameters can be calculated. Additionally, by placing actuators in the footwear and measuring gait patterns, one can generate biofeedback to assist patients suffering from stroke. The same set of pressure sensors and inertial sensors can also be used in tracking posture and activity recognition and energy expenditure estimation. These and other important applications have driven footwear wearable technology to its present day state and continue to drive the technology even further.

In this work we review advancements in footwear-based wearable systems based on their target application scenarios. Applications described in the work include those that focus on gait monitoring, plantar pressure measurement, posture and activity classification, body weight and energy expenditure estimation, biofeedback, navigation, and fall risk applications. For each application, example systems are taken from published research and consumer products. Keywords such as 'gait monitoring systems', 'plantar pressure measurement', and others were searched in databases such as IEEE Xplore, PubMed, and Google Scholar. Literature that described portable or wearable systems that have sensors embedded in the shoes, insoles, sandals, or socks were included and the stationary systems were excluded from the review.

The article discusses the existing systems with respect to their hardware, sensor modalities, modes of data acquisition and data processing methodologies. Merits/demerits of each system are also pointed out. The work also attempts to shine a light on some of the most recent advancements happening in the field, as well as on the future direction for footwear-based wearable systems.

\section{Application Scenarios for Footwear-Based Wearable Systems}

\subsection{Gait Analysis}

A person's walk is characterized by their gait, which involves a repetitious sequence of limb motions to move the body forward while simultaneously maintaining stability [4]. Having a normal gait allows someone to remain agile so that they may easily change directions, walk up or down stairs, and avoid obstacles. Patients with neuromuscular disorders are likely to have abnormal gaits and suffer in their ability to perform locomotive activities. Objective measurement and analysis of gait patterns can help in the rehabilitation of such disabled individuals.

Figure 1a shows an illustration of an instrumented insole developed for gait monitoring by Crea et al. [5]. There are two kinds of parameters that are computed in gait monitoring applications: temporal and spatial. Some of the examples of the temporal gait parameters are cadence, stance time, step time, single support time, and double support time; while step length and stride length are examples for spatial gait parameters. Gait monitoring is one field of wearable computing where there are a considerably high number of footwear-based systems deployed. Many such systems are compared in Table 1. There are force plates available for gait analysis [6], and there are also systems that make use of the Kinect $[7,8]$; but footwear-based solutions are much better suited for uncontrolled free living conditions outside the laboratory environment. Footwear is also an ideal location to measure the gait parameters as these applications measure the parameters involved in the movement of foot.

By utilizing pressure-sensitive elements, such as force sensitive resistors (FSR), for gait monitoring, temporal parameters such as cadence, step time, stance time and others can be computed. This is done utilizing the heel strike and toe off time events (Figure 1b). The gait monitoring applications extract gait event information from the changes in pressure sensor readings and not the absolute pressure. Hence, the pressure sensing does not need high spatial resolution, so only a few pressure elements are used in such applications. High pressure measurement precision is also not needed, and for that reason, sometimes these are called foot switches. 


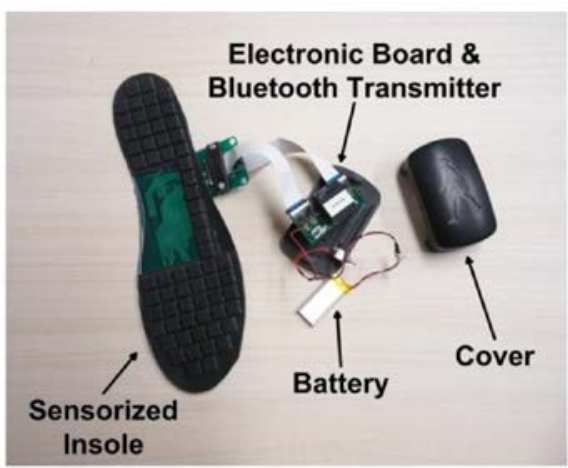

a

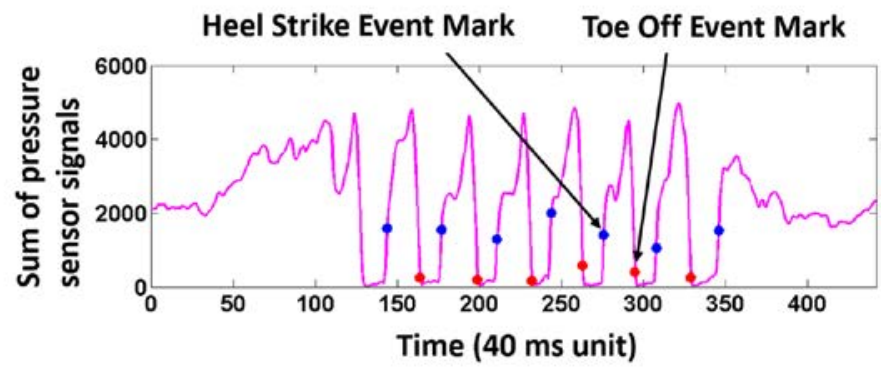

b

Figure 1. (a) Instrumented footwear for gait monitoring presented by and Crea et al. [5]; (b) marking of heel strike and toe off time instances from the pressure sensor signals. 
Table 1. Comparison of footwear-based gait monitoring systems.

\begin{tabular}{|c|c|c|c|c|c|c|}
\hline & Bamberg et al. [9] & Sazonov et al. [10] & Chen et al. [11] & Mariani et al. [12] & Leunkeu et al. [13] & Rampp et al. [14] \\
\hline Sensing element & $\begin{array}{l}\text { FSR, polyvinylidene } \\
\text { fluoride strip, } \\
\text { accelerometer, } \\
\text { gyroscope }\end{array}$ & FSR, accelerometer & $\begin{array}{l}\text { FSR, accelerometer, } \\
\text { gyroscope }\end{array}$ & $\begin{array}{l}\text { Accelerometer and } \\
\text { gyroscope }\end{array}$ & $\begin{array}{l}\text { Parotec plantar } \\
\text { pressure insoles }\end{array}$ & $\begin{array}{l}\text { Accelerometer and } \\
\text { gyroscope }\end{array}$ \\
\hline Sampling frequency & $75 \mathrm{~Hz}$ & $25 \mathrm{~Hz}$ & $50 \mathrm{~Hz}$ & $200 \mathrm{~Hz}$ & $150 \mathrm{~Hz}$ & $102.4 \mathrm{~Hz}$ \\
\hline $\begin{array}{l}\text { Data transmission } \\
\text { method }\end{array}$ & RF to PC & $\begin{array}{l}\text { Bluetooth to } \\
\text { Smartphone }\end{array}$ & RF to PC & SD card logged & SD card logged & $\begin{array}{l}\text { Data logged using } \\
\text { Shimmer } 2 R^{\circledR}[15]\end{array}$ \\
\hline Data analysis method & $\begin{array}{l}\text { PC post processing to } \\
\text { compute gait } \\
\text { parameters }\end{array}$ & $\begin{array}{l}\text { PC post processing to } \\
\text { compute gait } \\
\text { parameters }\end{array}$ & $\begin{array}{l}\mathrm{PC} \text { post processing to } \\
\text { predict abnormal gait }\end{array}$ & $\begin{array}{l}\text { PC post processing to } \\
\text { compute gait } \\
\text { parameters }\end{array}$ & PC post processing & PC post processing \\
\hline $\begin{array}{l}\text { Real time gait } \\
\text { monitoring }\end{array}$ & NA & NA & NA & NA & NA & NA \\
\hline $\begin{array}{l}\text { Clinical/Validation } \\
\text { Study }\end{array}$ & $\begin{array}{c}\text { Computed gait } \\
\text { parameters of } \\
10 \text { healthy subjects } \\
\text { and five Parkinson } \\
\text { Disease (PD) patients }\end{array}$ & $\begin{array}{l}\text { Computed gait } \\
\text { parameters of } \\
16 \text { healthy subjects } \\
\text { and seven post } \\
\text { stroke patients }\end{array}$ & NA & $\begin{array}{c}\text { Computed gait } \\
\text { parameters of } 10 \mathrm{PD} \\
\text { patients and } \\
10 \text { healthy subjects }\end{array}$ & $\begin{array}{l}\text { Computed gait } \\
\text { parameters of } \\
15 \text { Cerebral } \\
\text { Palsy }(\mathrm{CP}) \text { and } \\
10 \text { normal children }\end{array}$ & $\begin{array}{l}\text { Stride parameter } \\
\text { calculation } 116 \\
\text { geriatric patients }\end{array}$ \\
\hline $\begin{array}{l}\text { Gait analysis } \\
\text { performed }\end{array}$ & $\begin{array}{l}\text { Computed maximum } \\
\text { pitch, minimum pitch, } \\
\text { stride length, stride } \\
\text { time, \% stance time }\end{array}$ & $\begin{array}{l}\text { Computed cadence, } \\
\text { step time, cycle time, } \\
\text { swing } \% \text {, stance } \% \text {, } \\
\text { single support } \% \text {, } \\
\text { double support \% }\end{array}$ & $\begin{array}{l}\text { Classified } 5 \text { different } \\
\text { gait types: Normal, } \\
\text { toe in, toe out, over } \\
\text { supination and heel } \\
\text { walking }\end{array}$ & $\begin{array}{l}\text { Computed turning } \\
\text { angle, stride velocity, } \\
\text { stride length, swing } \\
\text { width, path length }\end{array}$ & $\begin{array}{c}\text { Computed step } \\
\text { duration, double } \\
\text { support time, ground } \\
\text { contact time, velocity, } \\
\text { step frequency and } \\
\text { stride length }\end{array}$ & $\begin{array}{l}\text { Computed stride length, } \\
\text { stride time, swing time, } \\
\text { and stance time }\end{array}$ \\
\hline $\begin{array}{l}\text { Gold Standard } \\
\text { Comparison }\end{array}$ & $\begin{array}{l}\text { Validated against } \\
\text { MGH BMLs Selspot II }\end{array}$ & $\begin{array}{l}\text { Validated against } \\
\text { GaitRite }\end{array}$ & NA & $\begin{array}{c}\text { Validated against } \\
\text { optical system by Vicon } \\
\text { Motion Systems Ltd }\end{array}$ & NA & $\begin{array}{l}\text { Validated against } \\
\text { GaitRite }\end{array}$ \\
\hline Accuracy & $\begin{array}{l}\text { Highest mean } \\
\text { percentage change of } \\
15.6 \% \text { in maximum } \\
\text { pitch and least mean } \\
\text { percentage change of } \\
6.5 \% \text { in stride length }\end{array}$ & $\begin{array}{l}\text { Highest relative error } \\
\text { of } 18.7 \% \text { for step time } \\
\text { and least relative } \\
\text { error of } 2.7 \% \text { for } \\
\text { cycle time }\end{array}$ & $\begin{array}{l}\text { Highest accuracy of } \\
97 \% \text { for detecting } \\
\text { over supination and } \\
\text { least accuracy of } \\
82.3 \% \text { for toe in }\end{array}$ & $\begin{array}{c}\text { Stride velocity and } \\
\text { stride length } \\
\text { accuracy } \pm \text { precision of } \\
2.8 \pm 2.4 \mathrm{~cm} / \mathrm{s} \text { and } \\
1.3 \pm 3.0 \mathrm{~cm}\end{array}$ & NA & $\begin{array}{c}\text { Correlation of } 0.93 \text { and } \\
0.95 \text { between GaitRite } \\
\text { and this system in stride } \\
\text { length and stride time. } \\
\text { Absolute error of stride } \\
\text { length was } 6.26 \mathrm{~cm} \text { in } \\
\text { normal walking }\end{array}$ \\
\hline
\end{tabular}


Table 1. Cont.

\begin{tabular}{|c|c|c|c|c|c|c|}
\hline & Kong et al. [16] & Liu et al. [17] & González et al. [18] & Crea et al. [5] & Wu et al. [19] & Ferrari et al. [20] \\
\hline Sensing element & $\begin{array}{c}\text { Custom air pressure } \\
\text { sensor }\end{array}$ & $\begin{array}{c}\text { Triaxial force sensors } \\
\text { for measuring GRF } \\
\text { and COP }\end{array}$ & $\begin{array}{c}\text { FSR and } \\
\text { accelerometer }\end{array}$ & Optoelectronic sensing & $\begin{array}{c}\text { Fiber based pressure } \\
\text { sensors }\end{array}$ & $\begin{array}{c}\text { Accelerometer and } \\
\text { gyroscope }\end{array}$ \\
\hline Sampling frequency & $200 \mathrm{~Hz}$ & $100 \mathrm{~Hz}$ & $50 \mathrm{~Hz}$ & $18.75 \mathrm{~Hz}$ & $30 \mathrm{~Hz}$ & $200 \mathrm{~Hz}$ \\
\hline $\begin{array}{l}\text { Data transmission } \\
\text { method }\end{array}$ & $\begin{array}{l}\text { NI Compactrio } \\
\text { data logger }\end{array}$ & $\begin{array}{c}\text { Storing data in } \\
\text { MCU's SRAM and } \\
\text { offline uploading } \\
\text { to PC }\end{array}$ & $\begin{array}{l}\text { Bluetooth to } \\
\text { Smartphone }\end{array}$ & Bluetooth to PC & SD card logging & Bluetooth to smartphone \\
\hline Data analysis method & PC Post processing & PC post processing & PC Post processing & PC Post processing & PC post processing & PC post processing \\
\hline $\begin{array}{c}\text { Real time } \\
\text { gait monitoring }\end{array}$ & NA & NA & Android smartphone & $\begin{array}{l}\text { LabVIEW user } \\
\text { interface in PC }\end{array}$ & NA & Android smartphone \\
\hline $\begin{array}{l}\text { Clinical/Validation } \\
\text { Study }\end{array}$ & NA & $\begin{array}{l}\text { Validated on seven } \\
\text { healthy subjects. }\end{array}$ & $\begin{array}{l}\text { Validated on six } \\
\text { healthy subjects. }\end{array}$ & $\begin{array}{c}\text { Validated on } \\
2 \text { healthy subjects }\end{array}$ & NA & $\begin{array}{c}\text { Validated on } \\
12 \text { healthy subjects and } \\
16 \text { PD subjects }\end{array}$ \\
\hline $\begin{array}{l}\text { Gait analysis } \\
\text { performed }\end{array}$ & $\begin{array}{c}\text { Fuzzy logic based gait } \\
\text { phase abnormality } \\
\text { detection }\end{array}$ & $\begin{array}{l}\text { Average coefficient of } \\
\text { variation for } \\
\text { three-directional GRF } \\
\text { to evaluate extrinsic } \\
\text { gait variability }\end{array}$ & $\begin{array}{l}\text { A fuzzy rule-based } \\
\text { inference algorithm to } \\
\text { detect each of the } \\
\text { gait phases. }\end{array}$ & $\begin{array}{l}\text { Computed stance and } \\
\text { swing duration of both } \\
\text { feet; duration of the } \\
\text { double-support phases; } \\
\text { and step cadence of } \\
\text { both feet. }\end{array}$ & $\begin{array}{l}\text { Methodology for local } \\
\text { randomized selective } \\
\text { sensing based on } \\
\text { pressure signal maps. }\end{array}$ & $\begin{array}{l}\text { Computation of step } \\
\text { length, stride time, stride } \\
\text { length and stride velocity }\end{array}$ \\
\hline $\begin{array}{l}\text { Gold Standard } \\
\text { Comparison }\end{array}$ & NA & $\begin{array}{l}\text { Validated against } \\
\text { Kyowa force plate } \\
\text { and optical motion } \\
\text { analysis system by } \\
\text { NAC Image Tech }\end{array}$ & NA & $\begin{array}{l}\text { Validated against AMTI } \\
\text { force plate }\end{array}$ & NA & $\begin{array}{l}\text { Validated against } \\
\text { GaitRite }\end{array}$ \\
\hline Accuracy & $\begin{array}{c}\text { Proposed sensing } \\
\text { unit showed } \\
\text { a repeatability of } 97 \% \text {. } \\
\text { Abnormal gait } \\
\text { monitoring results } \\
\text { weren't quantified }\end{array}$ & $\begin{array}{c}\text { RMS error of } \\
7.2 \% \pm 0.8 \% \text { and } \\
9.0 \% \pm 1 \% \text { for } \\
\text { transverse component } \\
\text { of ground reaction } \\
\text { force and } \\
1.5 \% \pm 0.9 \% \text { for } \\
\text { vertical component }\end{array}$ & $\begin{array}{l}92 \% \text { cross validation } \\
\text { accuracy for the } \\
\text { probabilistic classifier }\end{array}$ & $\begin{array}{l}\text { Pearson correlation } \\
0.89 \pm 0.03 \text { with the } \\
\text { force plate }\end{array}$ & $\begin{array}{l}\text { Normalized mean } \\
\text { square error of the } \\
\text { proposed sensing } \\
\text { methodology is } \\
\text { within } 10 \% \text {, } \\
\text { compared against } \\
\text { actual signal }\end{array}$ & $\begin{array}{l}\text { Over the } 1314 \text { strides, } \\
\text { the total root mean } \\
\text { square difference on step } \\
\text { length estimation } \\
\text { between this system and } \\
\text { gold standard was } 2.9 \%\end{array}$ \\
\hline
\end{tabular}


For computation of temporal gait parameters, a higher sampling frequency means better time resolution, resulting in higher accuracy in the computed parameters. However, there is a tradeoff between battery life, sampling frequency, and accuracy (applicable to all of the systems discussed in this work). A higher sensor sampling frequency will result in higher power consumption by the system, resulting in a shortened battery life; while a lower sampling frequency may decrease the accuracy of the system. The work in [5] has used $18.75 \mathrm{~Hz}$, however it has not yet been fully validated. In [10], it was shown that $25 \mathrm{~Hz}$ is sufficient for gait parameter extraction for walking at the speed of $2 \mathrm{~km} / \mathrm{h}$ or less. However, our ongoing work suggests that for computation of parameters such as double support time, especially during walking at speeds more than $4 \mathrm{~km} / \mathrm{h}$ or running, $25 \mathrm{~Hz}$ is insufficient. Sampling frequencies of greater than $50 \mathrm{~Hz}$, as reported in [9], will provide a better accuracy for all the gait parameter computations.

Inertial sensors such as an accelerometer in conjunction with gyroscope can be used in the computation of distance or elevation. Hence, these inertial sensors are utilized in the computation of spatial gait parameters such as step length or stride length, as shown in [9].

Only a couple of the works discussed the expected battery life for their systems. In [5] it was reported that a battery life of about $20 \mathrm{~h}$ is achievable, which can enable almost two days of wear in real life situations. In [19], $10 \mathrm{~h}$ of usage time on single charge is reported, which can enable one day of wear on full charge. However, in [19], having this particular lithium polymer battery under the foot may be potentially hazardous.

From connectivity perspective, Bluetooth is quite commonly used in many of the footwear-based systems as done in $[5,10,18]$ and others. A lower power consumption version of Bluetooth, named Bluetooth Low Energy (BLE), is coming to prominence in the recent years and there are a few footwear-based systems that have utilized BLE, [21,22], which will be discussed in the later sections. The study in [21] has reported more than two orders of magnitude in power savings when utilizing BLE compared to traditional Bluetooth.

With regards to data processing, many gait monitoring applications in their current form rely on collecting the data from human subject experiments and a PC performing post processing, as in most of the cases as shown in Table 1. Real-time gait monitoring and visual feedback can help in clinical applications and González et al. [18], Ferrari et al. [20], and Crea et al. [5] have taken this into account.

There are a few works that have used gait information obtained from footwear-based systems in pattern recognition. Huang et al. [23] identified a human subject based on the wearer's gait against eight other human subjects. Jochen Klucken et al. [24] were able to successfully distinguish PD patients from healthy subjects with an accuracy of $81 \%$. Jens Barth et al. [25] have presented a methodology to search for patterns matching a pre-defined stride template from footwear sensor data, to automatically segment single strides from continuous movement sequences.

All of the footwear-based solutions listed are research prototypes and some of them $[9,11]$ are primarily suited for laboratory studies. On the other hand, Sensoria ${ }^{\circledR}$ has developed commercial instrumented socks for gait monitoring [26]. The associated smartphone application running on iOS or Android is intended to help runners and provides real-time feedback on foot landing patterns, cadence and other important gait characteristics. Technical characteristics of the Sensoria product were not available at the time of this review.

Systems in $[5,11,19,23]$ would need further human subject studies as they have not yet been fully tested. Additionally, it is important to note that none of the above-described systems have undergone a longitudinal free-living study, which is essential to understand the gait behavior of wearers in community living. Development and full-fledged validation of a socially acceptable, user friendly, and reliable footwear-based gait monitor well suited for longitudinal studies is still an open challenge in the field that needs to be addressed.

\subsection{Plantar Pressure Measurement}

Plantar pressure is the pressure distribution between the foot and the support surface during everyday locomotion activities. Foot plantar pressure measurement applications focus on measuring 
of the pressure distribution between the foot and the support surface. Figure 2a shows an illustration of a plantar pressure map during one stance phase (heel strike to heel off) of a healthy individual [27].

The foot and ankle provide the support and flexibility for weight bearing and weight shifting activities such as standing and walking. During such functional activities, plantar pressure measurement provides an indication of foot and ankle functions. Plantar pressure measurement has been recognized as an important area in the assessment of patients with diabetes [28]. The information derived from plantar pressure measurement can also assist in identification and treatments of the impairments associated with various musculoskeletal and neurological disorders [29]. Hence, plantar pressure measurement is important in the area of biomedical research for gait and posture analysis [11,30,31], sport biomechanics [32,33], footwear and shoe insert design [34], and improving balance in the elderly [35], among other applications.

For all the above applications, there are solutions that utilize non-wearable systems, such as force plates and force mapping systems [36], but footwear is an ideal location for such measurements. Footwear-based platforms also offer much higher portability and can potentially enable monitoring outside of the laboratory, in uncontrolled, free living applications. Almost all the footwear-based applications reviewed in this work have some form of plantar pressure sensing elements built in to them; however, in this section we place an emphasis on the footwear systems that deal explicitly with plantar pressure measurement. These systems are compared in Table 2. Figure $2 \mathrm{~b}$ shows the F-scan ${ }^{\circledR}$ system by Tekscan, Inc. (Boston, MA, USA) [37].

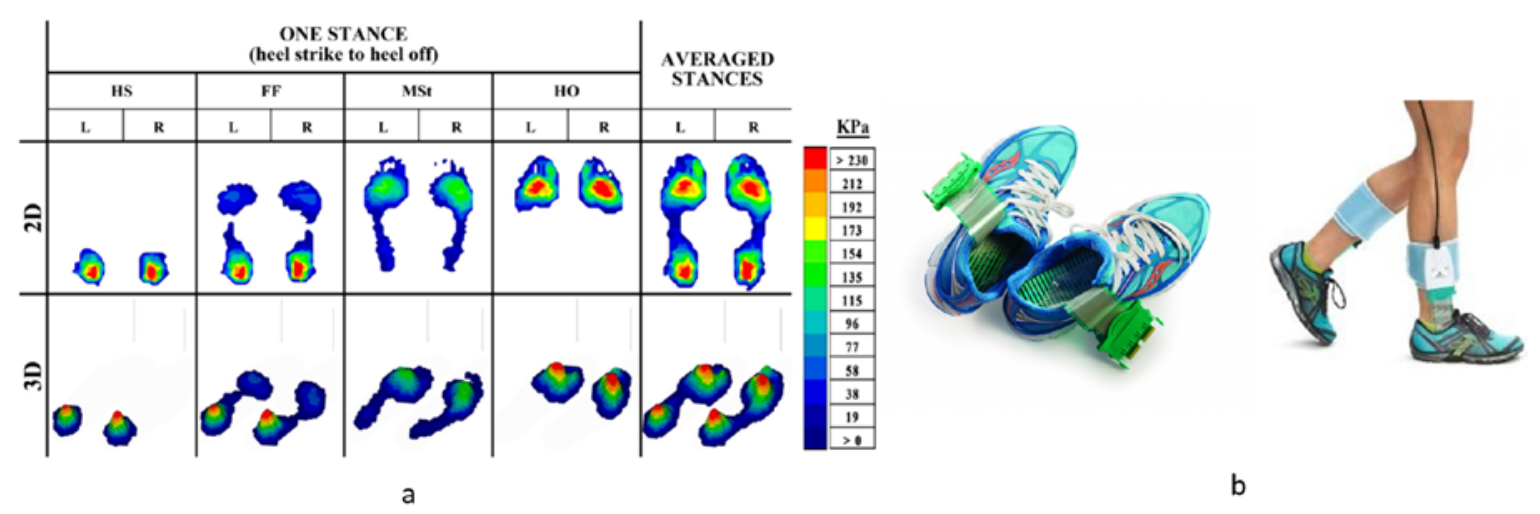

Figure 2. (a) Plantar pressure map during one stance [27]. HS—heel strike, FF—foot flat, MSt—mid stance, HO-heel off; and (b) F-Scan ${ }^{\circledR}$ System, courtesy of Tekscan, Inc. (Boston, MA, USA). 
Table 2. Comparison of plantar pressure measurement systems.

\begin{tabular}{|c|c|c|c|c|c|c|}
\hline & Adin Ming et al. [38] & Lin Shu et al. [39] & Saito et al. [40] & TekScan F-Scan ${ }^{\circledR}[37]$ & Novel Pedar ${ }^{\circledR}[41]$ & Orpyx $\log R^{\circledR}[42]$ \\
\hline Sensing element & $\begin{array}{l}\text { Piezo resistive material, } \\
\text { total } 75 \text { nodes }\end{array}$ & $\begin{array}{l}\text { Resistive fabric sensor } \\
\text { array, six sensor array }\end{array}$ & $\begin{array}{l}\text { Pressure sensitive } \\
\text { conductive rubber }\end{array}$ & $\begin{array}{l}\text { Fabricated resistive insole, } \\
960 \text { sensing elements }\end{array}$ & $\begin{array}{l}\text { Capacitive sensing } \\
\text { element, } 256 \text { nodes }\end{array}$ & $\begin{array}{l}\text { The system has custom-built } \\
\text { force sensor array of } 8 \text { sensors }\end{array}$ \\
\hline Device usage & $\begin{array}{l}\text { Academic research } \\
\text { prototype }\end{array}$ & $\begin{array}{l}\text { Academic research } \\
\text { prototype }\end{array}$ & $\begin{array}{l}\text { Academic research } \\
\text { prototype }\end{array}$ & Commercial & Commercial & Commercial \\
\hline Sampling frequency & $13 \mathrm{~Hz}$ & $100 \mathrm{~Hz}$ & $50 \mathrm{~Hz}$ & Up to $750 \mathrm{~Hz} *$ & $78 \mathrm{~Hz}$ & $100 \mathrm{~Hz}$ \\
\hline $\begin{array}{c}\text { Sensor data } \\
\text { transmission method }\end{array}$ & Bluetooth & Bluetooth & Wired to PC & $\begin{array}{l}\text { PC tethering, data logging, } \\
\text { or Bluetooth }\end{array}$ & $\begin{array}{l}\text { Bluetooth/SD card } \\
\text { logging }\end{array}$ & Bluetooth \\
\hline Visualization method & $\begin{array}{l}\text { Real time visualization } \\
\text { of plantar pressure } \\
\text { distribution in PC }\end{array}$ & $\begin{array}{l}\text { Real-time visualization } \\
\text { of mean pressure, peak } \\
\text { pressure, center of } \\
\text { pressure (COP), and } \\
\text { speed of COP, in PC } \\
\text { and smartphone }\end{array}$ & $\begin{array}{l}\text { Visualization of } \\
\text { plantar pressure } \\
\text { distribution in PC } \\
\text { after data logging }\end{array}$ & $\begin{array}{l}\text { Real-time visualization of } \\
\text { plantar pressure } \\
\text { distribution in PC }\end{array}$ & $\begin{array}{c}\text { Real time } \\
\text { visualization of } \\
\text { plantar pressure } \\
\text { distribution in PC }\end{array}$ & $\begin{array}{l}\text { Real time visualization of } \\
\text { plantar pressure distribution } \\
\text { in iPhone }\end{array}$ \\
\hline Validation & $\begin{array}{l}\text { Validated against the } \\
\text { standard force plate } \\
\text { and the measured } \\
\text { plantar forces showed } \\
R^{2} \text { value of } 0.981\end{array}$ & $\begin{array}{l}\text { Relative mean } \\
\text { difference of } 5 \% \text { in } \\
\text { plantar pressure against } \\
\text { standard force plate }\end{array}$ & $\begin{array}{l}\text { Validated against } \\
\text { F-scan. difference in } \\
\text { computed plantar } \\
\text { pressure varied from } \\
-4 \% \text { to } 18 \%\end{array}$ & $\begin{array}{l}\text { Multiple validation studies } \\
\text { as reported in [43-47] have } \\
\text { validated the system }\end{array}$ & $\begin{array}{l}\text { Multiple validation } \\
\text { studies [46-48] have } \\
\text { validated the system }\end{array}$ & $\begin{array}{l}\text { A validation study in [49] } \\
\text { reported } \mathrm{r}^{2} \text { of } 0.86 \text { in plantar } \\
\text { pressure measurement against } \\
\text { (undisclosed) gold standard }\end{array}$ \\
\hline
\end{tabular}

* Up to $100 \mathrm{~Hz}$ when wireless data collection is used. 
As seen in the Table 2, the sensing nodes for plantar pressure measurement application are much denser compared to those used in gait monitoring or activity monitoring, with the F-scan ${ }^{\circledR}$ system using as many as 960 sensing elements. This is because plantar pressure measurement applications demand the estimation of the absolute pressure that is exerted at different locations of the foot; while in activity and gait monitoring applications $[7,30]$, it is more important to capture the relative changes in the pressure levels than the actual pressure values as previously discussed. F-scan ${ }^{\circledR}$ [29] can be used for the pressure ranges of 345 to $825 \mathrm{kPa}$, while Pedar ${ }^{\circledR}$ from Novel, gmbh (Munich, Germany) [31] can be used in the range of $15-600 \mathrm{kPa}$ or $30-1200 \mathrm{kPa}$.

Since plantar pressure measurement applications are concerned more with the absolute pressure measurement and not the events, time resolution in the data from such systems do not play as vital a role as in gait monitoring. Sampling frequencies of as low as $13 \mathrm{~Hz}$ up to $750 \mathrm{~Hz}$ have been used in systems as shown in Table 2.

A potential concern with the pressure sensing elements in the footwear is their drift over time, which will become important when the systems are used in real life settings for long periods of time. A periodic recalibration would be needed to obtain repeatability as done for the case of F-scan ${ }^{\circledR}$ in $[45,50]$. Studies in $[46,47]$ have suggested that capacitive sensing based Novel Pedar ${ }^{\circledR}$ has higher repeatability and accuracy when compared to the resistive sensing based Tekscan F-scan ${ }^{\circledR}$ systems. However, out of all the systems reviewed, F-scan offers the highest spatial resolution with 960 sensing elements in the insole. The F-scan ${ }^{\circledR}$ system has a reported $2 \mathrm{~h}$ of battery life, which is rather low. The $\log \mathrm{R}^{\circledR}$ by Orpyx, Inc. (Calgary, AB, Canada) [42] has reported 8-12 h of battery life, long enough to last through a regular day of wear.

All of the systems listed in Table 2 have connectors on the insoles which need to be connected to the microcontroller unit (MCU) outside of the footwear. This can limit usability in free living conditions by causing the footwear look out of the ordinary and feel uncomfortable. The system presented in [40] has a wired PC interface, which can limit use even in a controlled laboratory setup.

These above solutions measure the vertical force component of the ground reaction force (GRF), and Liu et al. [51] have presented a wearable force plate system for the continuous measurement of tri-axial ground reaction force in biomechanical applications. This system not only measures the vertical component of the GRF during ambulatory phase, but also measures transverse components of the GRF (anterior-posterior and medial-lateral). However, comfort levels wearing such systems made with tri-axial force sensors under heel may be questionable, as the sensor itself is $5 \mathrm{~mm}$ tall and it would be rather uncomfortable below the heel. Under the arch of the foot may be a better option for placing these sensors.

\subsection{Posture and Activity Recognition, and Energy Expenditure Estimation (EE)}

The ever increasing problem of obesity has brought immense importance to study in the field of posture and activity recognition and energy expenditure estimation. Weight gain is caused by a sustained positive energy balance, where daily energy intake is greater than daily energy expenditure. This is typically caused by living a sedentary lifestyle [52,53]. In [14] it was reported that obese individuals spend more time seated and less time ambulating than lean individuals. More than one third of U.S. adults are obese [54] and quantifying posture and activity allocation to help keep track of energy expenditure utilizing wearable sensors is quickly becoming a part of weight management programs. The applications extend beyond weight management programs, as posture and activity monitoring is an important aspect in the rehabilitation programs for post-stroke individuals [55]. Posture and activity classification is a large part of the consumer electronics industry's fitness segment. Fitness applications running on smartphones, smart watches, and fitness trackers are becoming common parts of modern daily life [56-60]. Almost all of these solutions are based on accelerometry and there are many published works on using accelerometer for posture and activity recognition [61-68]. There are also comparisons of commercially available accelerometry based activity and energy expenditure estimation (EE) monitors in [69-71]. In this section however, we focus only on footwear-based solutions used for posture and activity recognition, body weight, and EE estimation. 
There are several footwear-based systems for posture and activity recognition purposes, and an example of these are the SmartShoe system developed by Sazonov et al. [72] which have been validated extensively for posture and activity monitoring. They have been used with healthy subject groups [30,72,73], people with stroke [55,74] and children with cerebral palsy [75]. The most recent incarnation of the SmartShoe systems, named SmartStep by Hegde et al., has shown the capability to be accurate in posture and activity classification [21,76,77]. Chen et al. have designed a foot-wearable interface for locomotion mode recognition based on contact force distribution [78]. Kawsar et al. have developed a novel activity detection system using plantar pressure sensors and a smartphone [79]. Table 3 contains the comparison of these systems. Figure 3a shows a picture of SmartStep insole [80] and the associated Android application for daily activity monitoring.

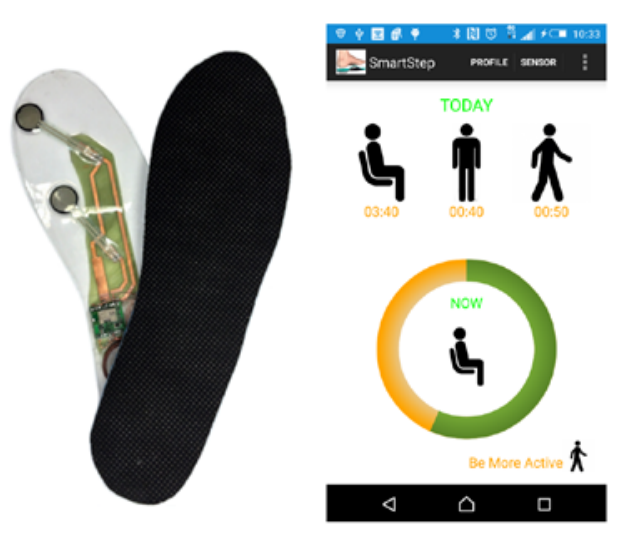

a

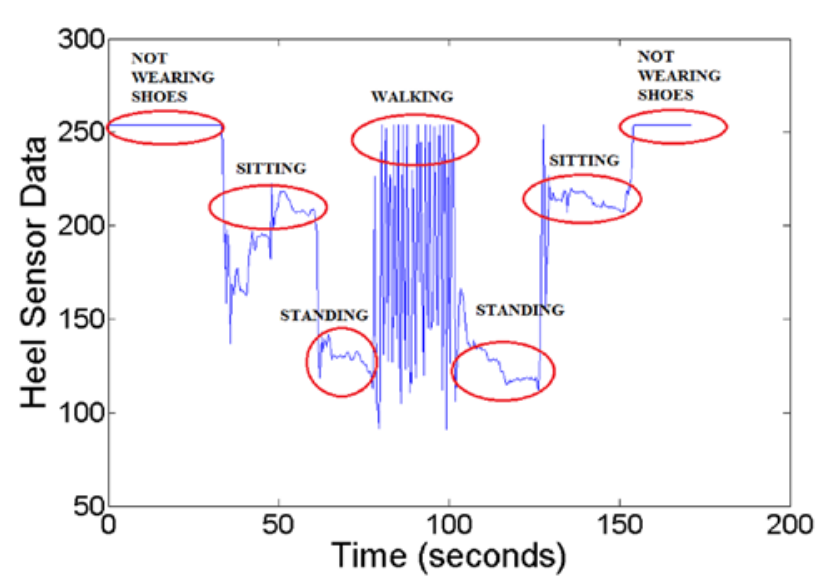

b

Figure 3. (a) SmartStep system by Hegde et al. [80]; and (b) heel pressure sensor signals for daily living activities [76]. 
Table 3. Comparison of footwear-based posture and activity recognition systems.

\begin{tabular}{|c|c|c|c|c|}
\hline & Sazonov et al. [55,72-74] & Hegde et al. $[21,76,77]$ & Chen et al. [78] & Kawsar et al. [79] \\
\hline Sensing element & $\begin{array}{l}\text { Five Interlink force sensitive } \\
\text { sensors FSR } 402 \text { in the insole, } \\
\text { accelerometer in the shoe clip on }\end{array}$ & $\begin{array}{l}\text { Three Interlink force sensitive } \\
\text { sensors FSR402, accelerometer, } \\
\text { gyroscope all in the insole }\end{array}$ & $\begin{array}{l}\text { Four FlexiForce A401 force } \\
\text { sensor from Tekscan }\end{array}$ & $\begin{array}{l}\text { Eight Fabric pressure sensors } \\
\text { reported in [39]. Accelerometer and } \\
\text { Gyroscope in the smartphone }\end{array}$ \\
\hline Sampling frequency & $25 \mathrm{~Hz}$ & $25 \mathrm{~Hz}-75 \mathrm{~Hz}$ & $100 \mathrm{~Hz}$ & $37 \mathrm{~Hz}$ \\
\hline Data transmission method & Bluetooth to smartphone & BLE to smartphone & RF module to PC & Bluetooth to smartphone \\
\hline Data processing method & $\begin{array}{l}\text { PC post processing for activity } \\
\text { classification using neural } \\
\text { network [81], decision trees [74], } \\
\text { and support vector machines } \\
\text { (SVM) [81] }\end{array}$ & $\begin{array}{l}\text { PC post processing for activity } \\
\text { classification utilizing } \\
\text { multinomial logistic } \\
\text { discrimination (MLD) [80] }\end{array}$ & $\begin{array}{l}\text { PC post processing for activity } \\
\text { classification using decision } \\
\text { trees [78] and linear } \\
\text { discriminant analysis [78] }\end{array}$ & $\begin{array}{l}\text { Four different decision trees to } \\
\text { classify activity from four sets of } \\
\text { sensors (left shoe, right shoe, } \\
\text { accelerometer, and gyroscope. } \\
\text { Majority voting to decide the } \\
\text { activity [79] }\end{array}$ \\
\hline Activities classified & $\begin{array}{l}\text { Sitting, standing, walking, upstairs, } \\
\text { downstairs, cycling }\end{array}$ & $\begin{array}{l}\text { Initial validation study } \\
\text { classified sitting, standing, } \\
\text { walking and cycling }\end{array}$ & $\begin{array}{l}\text { Sitting, standing, level } \\
\text { walking, obstacle clearance, } \\
\text { upstairs, downstairs }\end{array}$ & Sitting, standing, walking, running \\
\hline Real time activity feedback & Windows smartphone & Android smartphone & $\begin{array}{l}\text { PC post processing and no real } \\
\text { time feedback }\end{array}$ & Android smartphone \\
\hline Clinical/Validation Study & $\begin{array}{l}\text { Validated on stroke subjects }[55,82] \\
\text { and healthy subjects }[73,81]\end{array}$ & $\begin{array}{l}\text { Initial validation study on five } \\
\text { healthy subjects [80] }\end{array}$ & $\begin{array}{c}\text { Validated on five healthy } \\
\text { subjects and one subject with } \\
\text { amputee }\end{array}$ & NA \\
\hline Accuracy & $\sim 99 \%$ & $96 \%$ & $98.4 \%$ & $\sim 99 \%$ \\
\hline
\end{tabular}


All of the systems listed make use of various pressure sensors in order to determine the activity the user is undergoing. Pressure sensors can help to handle the ambiguity between weight bearing and non-weight bearing activities such as sitting and standing postures that cannot easily be determined using only accelerometry. An example of a pressure sensor signal located at heel for different daily living activities [76] is shown in Figure 3b. All of the systems utilize motion sensors such as accelerometers and the systems in $[77,79]$ have a gyroscope as well.

Similar to the gait monitoring systems, the pressure sensitive elements in the footwear for activity monitoring are used for marking the events. However, since changes in activity do not happen too often, a lower sampling frequency can also be used in activity classification to save battery power. In [83] it was shown that for accelerometer based daily activity classification, a $15 \mathrm{~Hz}$ sampling rate can provide a $85 \%$ classification accuracy. When it comes to footwear-based systems, as shown by works of Sazonov et al. even $1 \mathrm{~Hz}$ sampling rate can be used in monitoring of the daily activities with $93 \%$ accuracy [72], and as shown in [55,72-74], a $25 \mathrm{~Hz}$ sampling frequency can provide a $99 \%$ accurate activity classification. Other described systems also have a very high accuracy $(>96 \%$ across any system presented) in discriminating between the daily living activities of sitting, standing, walking, running, and cycling.

One of the limitations of footwear-based systems in activity monitoring is that they cannot be used in classifying upper body activities. To monitor upper body activities, additional sensors need to be worn on locations of the upper body. An example of such a system is the one presented by Ryan et al., who have used a wrist worn accelerometer along with the footwear system to classify daily living activities of ascending stairs, descending stairs, doing the dishes, vacuuming, and folding laundry, along with many athletic activities [84].

A long battery life is very important for the usability of these systems. Reports in $[21,72,85]$ have discussed the battery life of the corresponding systems and the SmartStep system in [21], stands out among these, with more than four days of operations on single charge in certain modes. The other two systems had battery lives of approximately $5 \mathrm{~h}$ on a single charge.

None of the above systems have undergone longitudinal free living studies. There are many factors that need to be effectively addressed to enable such studies in community living environments. Social acceptability, user friendly operation, comfort for wear and unobtrusiveness are some of the important challenges that need attention. SmartStep [21,77] has tried to address many of these challenges in footwear-based systems, with its socially acceptable design, low power usage, and completely unobtrusive form factor.

In terms of data processing, as reported in [81], support vector machines (SVM), being computationally expensive, are not suitable for implementing in portable electronic devices, such as smartphones, for real-time activity classification purposes. The study in [81] also reports that activity prediction models based on multinomial logistic discrimination (MLD) is computationally less expensive in terms of required memory space and execution time, and performs equally well in terms of accuracy, as compared to SVM. Binary decision trees [74,78,79], being a light-weight classifier, can possibly enable the implementation of predictive models on the sensor itself. This can potentially reduce the power consumption at the sensor node that would occur during the wireless connection events for raw data transmission.

With respect to energy expenditure (EE) estimation, there are relatively few footwear-based systems that are targeted for such applications. The SmartShoe platforms have been extensively validated in EE (in controlled laboratory environments) $[81,86]$. SmartShoes were compared against other accelerometry-based wearable devices and have proven to be equally or more accurate [87]. There are also several commercial footwear-based systems that can be used in EE, such as Lechal systems [88] and Lenovo SmartShoe [89], track their user's EE. The Lenovo ones have yet to enter the market.

In general, most of the present day solutions predict EE in terms of a steady state (sitting/standing/walking etc.). However, daily life is a mixture of both steady states and the continuous transitions between them. It is important to be able to quantify these in-between states in 
order to better estimate energy expenditure. Hence, we expect to see more and more research from a data processing perspective, to try to more accurately estimate EE in daily life. This may lead to the inclusion of several different sensors alongside activity predictors (heart rate, breathing rate and others) and novel data processing techniques, similar or better to the ones presented in [90] in order to better estimate EE.

Excessive body weight is the factor which defines obesity and body weight is also one of the most significant factors in calculating energy expenditure. Self-reporting of body weight can be highly erroneous [91]; hence, objective and autonomous measurements of body weight can help in accurate EE estimation and obesity treatment programs. Footwear is an ideal location for automatic body weight estimation systems since all of the body's weight is placed upon the feet when standing. A few footwear-based systems have been used for body weight estimation as done in [92,93]. The study in [92] reported root-mean squared error of $10.52 \mathrm{~kg}$ in estimating body weight of 9 study subjects, while the one in [93] reported an average overestimation error of $16.7 \mathrm{~kg}$ in estimating body weight of 10 study subjects. These works validate the approach, but there is a room for improving the accuracy of the footwear-based systems in estimating body weight.

In all, footwear-based systems have yet to become matured in the field of daily energy expenditure estimation. The problem with measuring daily energy expenditure utilizing footwear systems is that people, on average, may wear footwear for $12 \mathrm{~h}$ of their whole day. This leaves a good $50 \%$ of the activities outside the purview of such sensor systems. Though one may argue that the majority of the remaining $12 \mathrm{~h}$ may be spent sleeping (6-8 h), to measure accurate daily living energy expenditure, one may have to use other sensor systems in conjunction with footwear-based ones. These may include smartphones or smart watches, which are generally used even when someone is not wearing footwear at home. Another potential concern with footwear-based wearable systems for use in daily living is that people usually tend to use multiple pairs of footwear. Insole based systems would be much more practical, as users can insert the insole into any of their shoes that they want to wear. However, the actions of taking out the insole from the shoe and inserting into another may not be a very comfortable act and future research work in this area needs to address this challenge.

\subsection{Biofeedback}

The sensing technologies embedded in the footwear in conjunction with real-time feedback mechanisms can be deployed in rehabilitation programs of many health conditions. For example, utilizing the real-time gait information retrieved from the footwear, post stroke individuals can be given feedback to improve the asymmetry in their walking. An example of real-time monitoring of stroke patient's gait and generation of active feedback to improve the asymmetry is depicted in Figure 4a. The feedback can be delivered in visual, auditory, or tactile manners. Several footwear-based systems have been presented in biofeedback applications and are presented in Table 4 .

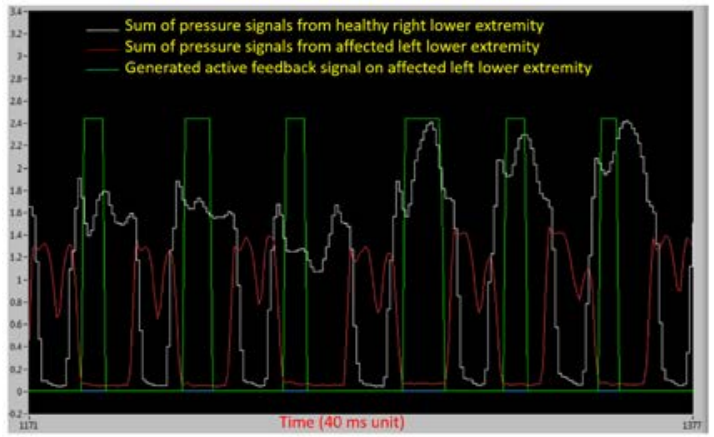

a

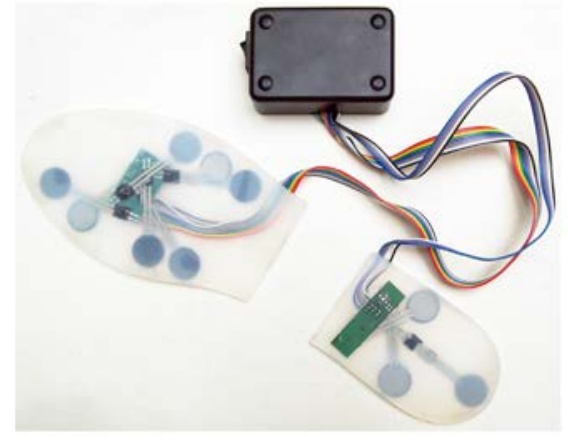

b

Figure 4. (a) Pressure sensor signals for asymmetric walking of a post-stroke subject and generation of active feedback [95]; and (b) biofeedback system presented by Bamberg et al. for stroke patients [96]. 
Table 4. Comparison of footwear-based biofeedback systems.

\begin{tabular}{|c|c|c|c|c|c|}
\hline & Orpyx $[42,49]$ & Khoo et al. [94] & Donovan et al. [97] & Hegde et al. [95] & Bamberg et al. [96] \\
\hline Sensing element & $\begin{array}{l}\text { Array of eight custom } \\
\text { pressure sensors }\end{array}$ & Six FSR sensors & $\begin{array}{l}\text { Pedar-x plantar pressure } \\
\text { system and EMG }\end{array}$ & Two FSR sensors & Ten FSR sensors \\
\hline Sampling frequency & Not reported & Not reported & $100 \mathrm{~Hz}$ & $20 \mathrm{~Hz}$ & $114 \mathrm{~Hz}$ \\
\hline Data transmission method & Wireless to smartwatch & $\begin{array}{l}\text { Wired connection to MCU } \\
\text { mounted on the lower back }\end{array}$ & Wired data logger & $\begin{array}{l}\text { Wired connection to MCU } \\
\text { mounted on the waist }\end{array}$ & Wireless to a portable PC \\
\hline Feedback methodology & $\begin{array}{l}\text { Smartwatch alerts when } \\
\text { dangerous pressure levels } \\
\text { are detected, so the user } \\
\text { can modify behavior and } \\
\text { avoid foot damage }\end{array}$ & $\begin{array}{l}\text { Tactile and auditory feedback } \\
\text { to correct the gait asymmetry }\end{array}$ & $\begin{array}{l}\text { Auditory biofeedback to } \\
\text { reduce the plantar pressure in } \\
\text { the area of lateral forefoot }\end{array}$ & $\begin{array}{l}\text { Tactile and auditory feedback } \\
\text { to correct the gait asymmetry }\end{array}$ & $\begin{array}{l}\text { Auditory feedback when the } \\
\text { symmetry ratio is less than one }\end{array}$ \\
\hline Computation method & $\begin{array}{l}\text { Computation of plantar } \\
\text { pressure levels for } \\
\text { diabetic patients }\end{array}$ & $\begin{array}{l}\text { Real-time computation of } \\
\text { stance time difference; swing } \\
\text { difference and generation of } \\
\text { active feedback }\end{array}$ & $\begin{array}{l}\text { Real-time computation of the } \\
\text { lateral column plantar } \\
\text { pressure and generation of } \\
\text { active biofeedback }\end{array}$ & $\begin{array}{l}\text { Real-time computation of } \\
\text { stance time difference and } \\
\text { generation of active feedback }\end{array}$ & $\begin{array}{l}\text { Real-time Matlab program running } \\
\text { on the PC that computes stance } \\
\text { time and gait symmetry ratio }\end{array}$ \\
\hline $\begin{array}{l}\text { Clinical/Validation } \\
\text { Study and results }\end{array}$ & NA & $\begin{array}{l}\text { Validation on four healthy } \\
\text { subjects and preliminary } \\
\text { validation on post stroke } \\
\text { patients. Gait parameters } \\
\text { validated against gold standard } \\
\text { (results not quantified) }\end{array}$ & $\begin{array}{l}\text { Validated on nine subjects } \\
\text { with chronic ankle instability. } \\
\text { Pronounced reductions in } \\
\text { peak pressure and pressure } \\
\text { time integral of the lateral } \\
\text { midfoot and lateral forefoot } \\
\text { with the biofeedback }\end{array}$ & $\begin{array}{l}\text { Validated on single stroke } \\
\text { subject. Subject showed } \\
\text { increased symmetry (step } \\
\text { time differential improved by } \\
48 \% \text { standard deviation for } \\
\text { the same increased by } 88 \% \text { ) }\end{array}$ & $\begin{array}{l}\text { Validated on three stroke patients. } \\
\text { One subject reduced trunk sway by } \\
85.5 \% \text {, and the other subject } \\
\text { reducing trunk sway by } 16.0 \% \text { and } \\
\text { increasing symmetry ratio toward } \\
\text { unity by } 26.5 \%\end{array}$ \\
\hline
\end{tabular}


Orpyx ${ }^{\circledR}$ have insole-based wearable systems that have been clinically validated [49] that give biofeedback to diabetic patients on a smartwatch, based on their plantar pressure profile [42]. This system makes use of a neurological rewiring phenomena in the brain, termed neuroplasticity. Khoo et al. [94] and, independently, Hegde et al. [95], and Bamberg et al. [96] (Figure 4b) have developed biofeedback devices for post-stroke patients to improve their gait asymmetry. Donovan et al. have worked on a shoe-based biofeedback device to assist people with chronic ankle instability [97].

Compared to gait and activity monitoring systems, biofeedback systems need to process the sensor data in real-time and also generate active feedback in real-time. Hence, these systems do not make use of elaborate sets of sensing elements. All of them use only pressure sensing elements as seen in Table 4, with Donovan et al. [97] being the only exception which uses EMG sensing along with pressure sensing. The sampling frequency can be as low as $20 \mathrm{~Hz}$ as shown by Hegde et al. [95], to save battery power. The computation methodologies need to be lightweight and cannot be running on a PC for providing real-time feedback.

All of the presented systems make use of auditory or tactile feedback mechanisms in order to communicate with the user. Accuracies of the systems in [94-96] seem comparable. Additionally, all of these were externally wired systems (which could potentially get in the way of their purpose). A full-fledged insole system would be much more attractive for real world usage. In [97], during experiments, the device threshold was adjusted using a small screw driver to turn the trimpot's dial. A more autonomous system than this would be attractive and make the device easier to use. Furthermore, all of these systems need further human subject validation.

Studies in [95-97] have showed significant improvements to the patients' health conditions. These results indicate that footwear-based systems could indeed be of great use in rehabilitation and should be further pursued.

\subsection{Fall Risk Assessment and Fall Detection Applications}

One of the primary causes for the disorders referenced in the sections above is aging. By 2040, the number of elderly people in U.S. is projected to be $21.7 \%$ of the total population [98], and the risk of falling in older adults is an important social problem to be addressed [99]. Systems that monitor the individual's gait over a long period of time and predict risk of falling are termed as fall risk assessment systems [100]. On the other hand, a fall detection system is a real time assistive device which has a main objective of alerting when a fall event occurs. We review such footwear-based systems in Table 5.

Doukas et al. have developed an advanced fall detection system based upon movement and sound data [101]. Wiisel is an advanced insole-based system that is used for fall risk applications [22]. Otis et al. [102] have come up with an efficient home-based falling risk assessment test using a smartphone and instrumented insole. Sim et al. [103] have worked on a fall detection algorithm for the elderly using acceleration sensors on the shoes. Majumder et al. have implemented a real-time smartshoe and smartphone-based fall risk prediction and prevention system [104]. Figure 5a shows the Wiisel system that is used for fall risk applications.

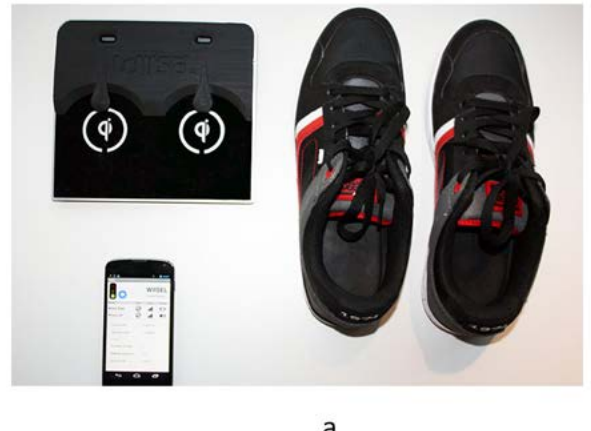

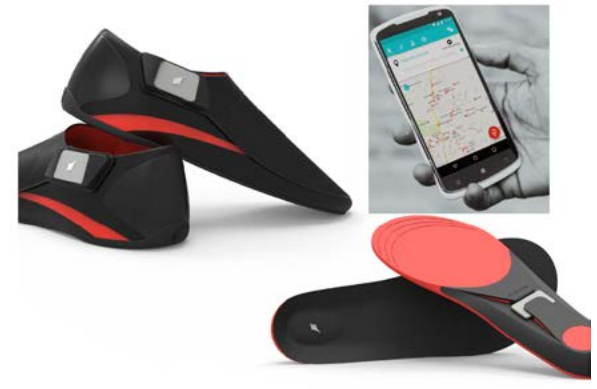

b

Figure 5. (a) Wiisel footwear system for fall risk application; and (b) Lechal system ${ }^{\circledR}$ for by Ducere Technologies Pvt. Ltd. (Secunderabad, Andhra Pradesh, India). 
Table 5. Comparison of footwear-based systems in fall risk applications.

\begin{tabular}{|c|c|c|c|c|c|}
\hline & Doukas et al. [101] & Wiisel [22] & Otis et al. [102] & Sim et al. [103] & Majumder et al. [104] \\
\hline Sensing element & $\begin{array}{l}\text { Accelerometers and } \\
\text { microphone }\end{array}$ & $\begin{array}{l}\text { Textile based smart insole, } \\
14 \text { pressure sensors, } \\
\text { accelerometer, gyroscope }\end{array}$ & $\begin{array}{l}\text { FSR, accelerometer and } \\
\text { bending sensor }\end{array}$ & Accelerometer & $\begin{array}{l}\text { Piezo resistive sensors } \\
\text { and inertial sensors from } \\
\text { smartphone }\end{array}$ \\
\hline Sampling frequency & NA & $30 \mathrm{~Hz}$ & $1000 \mathrm{~Hz}$ & $225 \mathrm{~Hz}$ & $25 \mathrm{~Hz}$ \\
\hline Data transmission method & ZigBee to PC & BLE to smartphone & Bluetooth to Android & Bluetooth to PC & Wi-Fi to iPhone \\
\hline Data analysis method & $\begin{array}{l}\text { Short time Fourier transform } \\
\text { and spectrogram analysis of the } \\
\text { data to detect fall incidents. The } \\
\text { classification of the sound and } \\
\text { movement data is performed } \\
\text { using Support Vector Machines }\end{array}$ & $\begin{array}{l}\text { Data is transmitted from } \\
\text { insoles to smartphone to } \\
\text { back end server. Stand- } \\
\text { alone program at the } \\
\text { server analyses the gait } \\
\text { and predicts fall risk }\end{array}$ & $\begin{array}{l}\text { Proposed an automatic } \\
\text { version of One-Leg } \\
\text { Standing (OLS) score, based } \\
\text { on COP measurements, for } \\
\text { risk of falling assessment }\end{array}$ & $\begin{array}{l}\text { Resultant acceleration } \\
\text { signal is averaged and a } \\
\text { threshold is used to } \\
\text { predict the risk of falling }\end{array}$ & $\begin{array}{l}\text { Tilt-invariant calculations } \\
\text { on accelerometer and } \\
\text { gyroscope data and usage } \\
\text { of decision trees to } \\
\text { classify high risk }\end{array}$ \\
\hline Clinical/Validation Study & $\begin{array}{l}\text { Three human subject validation } \\
\text { while they performed walk, } \\
\text { walk and fall, walk and run. } \\
100 \% \text { accuracy for fall detection } \\
\text { and } 96.72 \% \text { for walk and } \\
\text { run detection }\end{array}$ & $\begin{array}{c}\text { Validated on } 54 \text { elderly } \\
\text { participants [105], } \\
\text { results NA }\end{array}$ & $\begin{array}{l}\text { Twenty-three subject } \\
\text { human subject study [106] } \\
\text { including seven elderly and } \\
\text { four PD subjects. Results } \\
\text { suggest that the risk of } \\
\text { falling depends on the type } \\
\text { of ground }\end{array}$ & $\begin{array}{l}\text { Six subject test. } 81.5 \% \\
\text { sensitivity }\end{array}$ & $\begin{array}{c}\text { Fifteen subject study. } \\
\text { Subject dependent } \\
\text { individual model has high } \\
\text { accuracy but group model } \\
\text { has accuracy of only } 72 \%\end{array}$ \\
\hline
\end{tabular}


Accelerometer is the common sensing element across all the systems used in this field as seen in Table 5. Otis et al. [102] and Sim et al. [103] have used relatively high sampling frequencies, with Otis et al. using $1000 \mathrm{~Hz}$, though the reports did not substantiate the use.

Making the footwear systems comfortable for daily wear is a challenge and Wiisel insoles [22] have addressed this. These insoles are industrially built and with their built in wireless charging, this solution be used to benefit the elderly. However, people need to remove the insoles from their shoes in order to charge them. This is due to a limitation of the current version of the wireless charging standard Qi, which allows a maximum of $1.5 \mathrm{~cm}$ distance between the wireless power transmitter and receiver. This might be increased to 4 or $5 \mathrm{~cm}$ in the future and will remove the need for taking out the insoles for charging purposes. Systems other than Wiisel in this section are all laboratory prototypes.

If the systems have some kind of real time feedback, such as to call for help, that would be beneficial. Only [104] has any kind of real-time feedback implemented and adding this will be the next logical step for footwear systems used in fall risk applications.

Of the above mentioned systems, the one proposed by Doukas et al. [101] was the most accurate with $100 \%$ accuracy for fall detection. In that system, usage of microphone data along with accelerometer was novel. On the other hand, Sim et al. [103] system's $81.5 \%$ sensitivity is considerably low given the severity of misclassification.

\subsection{Navigation and Pedestrian Tracking Systems}

Another interesting area where footwear-based systems are being utilized is in the field of navigation assistive technologies and pedestrian tracking. These systems are aimed at providing assistance for the vision impaired, guiding emergency first responders, and work in augmented reality applications. In general, systems targeted for tracking utilize inertial sensors mounted on the footwear alongside GPS or radar; while navigation systems use actuators along with the sensors to guide the user in real-time. The key challenge for devices in this field is to be able to provide accurate location information without the need of a pre-installed infrastructure. In Table 6 several of these systems are reviewed. 
Table 6. Comparison of footwear-based navigation systems.

\begin{tabular}{|c|c|c|c|c|c|}
\hline & Schirmer et al. [107] & Bebek et al. [108] & Castaneda et al. [109] & Foxlin [110] & Lechal System ${ }^{\circledR}[88]$ \\
\hline Sensors & $\begin{array}{l}\text { Accelerometer, gyroscope, } \\
\text { magnetometer, compass, } \\
\text { smartphone GPS }\end{array}$ & $\begin{array}{l}\text { Accelerometer, gyroscope, } \\
\text { magnetometer heel of the } \\
\text { shoe. capacitive pressure } \\
\text { sensor at the heel }\end{array}$ & Accelerometer and gyroscope & $\begin{array}{l}\text { Accelerometer, gyroscope, } \\
\text { magnetometer }\end{array}$ & $\begin{array}{l}\text { Insole pressure sensors not } \\
\text { detailed. The electronics is } \\
\text { mentioned to be having } \\
\text { motion sensors }\end{array}$ \\
\hline Actuators & Two vibration motors & No actuator & No actuator & No actuator & Haptic or vibratory feedback \\
\hline $\begin{array}{l}\text { Sensor sampling } \\
\text { frequency }\end{array}$ & NA & NA & NA & $300 \mathrm{~Hz}$ & NA \\
\hline Data transmission method & BLE to iOS & Wired to laptop & Wired to laptop & RF to laptop & BLE to iOS or Android \\
\hline Data analysis method & $\begin{array}{l}\text { Phone computes walking } \\
\text { path and turns, and } \\
\text { communicates with the shoes } \\
\text { to trigger the actuators }\end{array}$ & $\begin{array}{l}\text { IMU bias compensation, } \\
\text { and computing of } \\
\text { position after zero velocity } \\
\text { update (using the } \\
\text { pressure sensor signals) } \\
\text { and slope correction }\end{array}$ & $\begin{array}{l}\text { Fuzzy logic procedure for } \\
\text { better foot stance phase } \\
\text { detection and an indirect } \\
\text { Kalman filter for drift } \\
\text { correction based on the } \\
\text { zero-updating measurement }\end{array}$ & $\begin{array}{l}\text { Zero velocity update of } \\
\text { accelerometer and gyroscope, } \\
\text { magnetometer calibration } \\
\text { followed by Geomagnetic } \\
\text { modeling and heading } \\
\text { drift Correction }\end{array}$ & NA \\
\hline Real time analysis & $\begin{array}{l}\text { Different vibration patterns } \\
\text { for different paths } \\
\text { (front, back, left, right) }\end{array}$ & Future Work & Real time analysis in laptop & Future Work & $\begin{array}{l}\text { Can provide turn-by-turn } \\
\text { navigation feedback }\end{array}$ \\
\hline Validation Study & $\begin{array}{l}\text { Twenty-one subject study } \\
\text { showed that } 99.7 \% \text { of the time } \\
\text { users correctly identified the } \\
\text { path and turns as fed back } \\
\text { by the shoes }\end{array}$ & $\begin{array}{l}\text { Six walking experiments } \\
\text { of half hour each, average } \\
\text { relative error } 0.35 \% \text { in the } \\
\text { final position tracked } \\
\text { by the system }\end{array}$ & $\begin{array}{c}\text { Three walking experiments, } \\
\text { average relative error of } 0.55 \% \\
\text { in the final position tracked } \\
\text { by the system }\end{array}$ & $\begin{array}{c}\text { Single user, } 118 \mathrm{~m} \text { walking } \\
\text { indoor with } 0.06 \% \text { error and } \\
741 \mathrm{~m} \text { outdoor experiment } \\
\text { with } 0.3 \% \text { error }\end{array}$ & NA \\
\hline
\end{tabular}


All of the described systems in Table 6 make use of accelerometer and gyroscope for computing the navigation path. These applications demand high temporal resolution in sensor sampling (as demonstrated by Foxlin [110] with $300 \mathrm{~Hz}$ ), because of complex computation (such as Kalman filtering [110]) and integration that needs to be performed to accurately determine the path.

Schirmer et al. [107] and Lechal System [88] provide feedback for real-time navigation. In order to use the system in [107], the user will need initial training to be able to understand the actuator patterns for front and back movement guidance, as they only use two actuators.

The Lechal ${ }^{\circledR}$ system by Ducere Technologies Pvt. Ltd. (Secunderabad, Andhra Pradesh, India) [88], being a commercial system, is industrially built (Figure $5 b$ ). Though initially intended as an assistance for a blind subject population, it can also be used by all for navigating purposes. Footwear feedback levels in this system are user configurable and it also provides options for configuration using voice commands.

The wired connection to a laptop limits the use of systems in $[109,110]$ for practical applications. Reported error in navigating a predefined path is very much comparable in all these systems and is less than $1 \%$ in the final position tracked by these systems.

\subsection{Other Enabling Technologies}

Energy harvesting from footwear is an area which has been of interest for a long time. As electronics are becoming smaller and smaller, the recent trend in wearable technology is to move towards smaller batteries or battery-less systems and to tap the energy needed from the human body or its motions. As early as 1995, Starner [41] reported that 67 watts of power are available in the heel movement of a $68 \mathrm{~kg}$ person who is walking at a pace of two steps per second. Even a fraction of that energy, if harvested, can easily power today's low power electronics. Many attempts are underway to tap the energy from body heat and the force produced during locomotive activities.

In Table 7 we compare several footwear-based systems that make use of energy harvesting methods. Shenck et al. have devised a methodology for energy scavenging with shoe-mounted piezoelectrics [111]. Orecchini et al. have come up with an inkjet-printed RFID system for scavenging walking energy [112]. Zhao et al. have developed a shoe-embedded piezoelectric energy harvester for wearable sensors [113]. Kymissis et al. have tested three different energy harvesting elements in their work [114]. Meier et al. have presented a piezoelectric energy-harvesting shoe system for podiatric sensing [115]. 
Table 7. Comparison of footwear-based energy harvesting systems.

\begin{tabular}{|c|c|c|c|c|c|}
\hline & Shenck et al. [111] & Orecchini et al. [112] & Zhao et al. [113] & Kymissis et al. [114] & Meier et al. [115] \\
\hline Energy harvesting element & $\begin{array}{c}\text { Piezoelectric lead zirconate } \\
\text { titanate (PZT) }\end{array}$ & Piezoelectric pushbutton & $\begin{array}{c}\text { Polyvinylidene } \\
\text { difluoride (PVDF) }\end{array}$ & $\begin{array}{l}\text { PZT, PVDF, and rotary } \\
\text { magnetic generator }\end{array}$ & $\begin{array}{l}\text { Vibrational transducer and } \\
\text { piezoelectric transducer }\end{array}$ \\
\hline $\begin{array}{l}\text { Placement of the energy } \\
\text { harvesting element }\end{array}$ & Insole & Underneath the shoe heel & Insole & $\begin{array}{l}\text { Insole for PZT and PVDF, } \\
\text { under the shoe for rotary } \\
\text { magnetic generator }\end{array}$ & Shoe heel \\
\hline $\begin{array}{l}\text { Validation application } \\
\text { scenario }\end{array}$ & Shoe-powered RF tag system & Self-powered RFID shoe & NA & A self-powered RF Tag System & $\begin{array}{l}\text { Self-powered gait data } \\
\text { capture system }\end{array}$ \\
\hline Salient features & $\begin{array}{l}\text { One of the first practical } \\
\text { systems demonstrating the } \\
\text { feasibility of the approach }\end{array}$ & $\begin{array}{l}\text { Emphasis was put on } \\
\text { designing RF antenna, in the } \\
\text { shape of a logo to make the } \\
\text { system socially acceptable }\end{array}$ & $\begin{array}{l}\text { Flexible and thin insole } \\
\text { platform }\end{array}$ & $\begin{array}{c}\text { Compared the efficiency and } \\
\text { practicality of } 3 \text { different energy } \\
\text { harvesting elements }\end{array}$ & $\begin{array}{l}\text { Were able to run a data } \\
\text { acquisition at } 5 \mathrm{~Hz} \text { from } \\
\text { harvested energy }\end{array}$ \\
\hline Reported harvested energy & $\begin{array}{c}8.4 \mathrm{~mW} \text { in a } 500-\mathrm{kohm} \text { load at } \\
0.9 \mathrm{~Hz} \text { walking pace }\end{array}$ & $\begin{array}{l}833 \mu \mathrm{J} \text { (test conditions not } \\
\text { reported) }\end{array}$ & $\begin{array}{l}1 \mathrm{~mW} \text { during a walk at } \\
\text { a frequency of } 1 \mathrm{~Hz}\end{array}$ & $\begin{array}{l}\text { From PZT } 1.8 \mathrm{~mW} \text {, from PVDF } \\
1.1 \mathrm{~mW} \text {, from rotary magnetic } \\
\text { generator } 0.23 \mathrm{~W}\end{array}$ & $10-20 \mu \mathrm{J}$ of energy per step \\
\hline
\end{tabular}


The energy can be harvested by vibration, compression, or bending produced in the footwear while the wearer performs motion activities such as walking. Piezoelectric lead zirconate titanate (PZT) and polyvinylidene difluoride (PVDF) are quite commonly used energy harvesting elements. PZT is a ceramic material, while PVDF is a plastic material.

From the study in [114] it is concluded that, even though mechanical systems such as the rotary magnetic element generate two orders of magnitude more energy than other systems, they are difficult to integrate into footwear. PZT and PVDF are more compact elements and can be much more easily integrated. The combination of the harvesting element and the placement of the element determine the resultant harvested energy.

Among the described works, Nathan S. Shenck [111] seems to be the one with the highest-reported power generated, but the system appears to be a laboratory prototype. The Rich Meier et al. solution [115] involves alteration of the shoes, which would limit its usage in generic footwear systems.

Though the amount of power generated by these systems is quite low, many of these systems were able to provide enough energy to drive low power RFID systems. For the systems demanding higher power, the resulting power from energy harvesting can be utilized in supplementing the power provided by the battery, to extend its runtime.

\section{Recent Trends and Future}

\subsection{Socially Acceptable and User Friendly Solutions}

It is important that footwear-based systems are as discrete and user friendly as possible. Most of the systems that are discussed in this work require a wireless/wired MCU placed outside the footwear. For free living daily life studies this may be a concern, and we are seeing work being done to move towards full-fledged insole-based systems. Insoles are now being equipped with all of the sensing elements, battery, recharging circuitry, and wireless interfaces $[22,77,88,91]$. Systems in $[49,88]$ have wireless charging capabilities which make them more user friendly.

The SmartStep [77] system has an over-the-air firmware upgrade feature, which can be used to easily configure the system for use in different application scenarios. The concept of real-time data collection and offline transmission of SmartStep, presented in [77], can be attractive for the elderly population as they do not need to carry smartphones with them to use the system. In this scenario, the sensor data is logged in the system's flash memory during wear and later is transferred to the base station when the insoles are being charged. These trends will hopefully continue and can help researchers, as well as users, to better utilize such systems.

\subsection{Footwear as Internet of Things (IoT) Devices and Big Data}

IoT is a field that is redefining the way people interact with their environment in their daily lives. IoT can enable every object we interact with (for example: key chains, coffee mug, cloths, appliances, and many more) to be a sensor and a minicomputer connected to the internet [116]. We foresee that footwear is going to become a part of the IoT revolution soon and can help people become more connected and help them better manage their lives. The application scenarios such as gait and activity monitoring, fall risk/fall detection, and others, can take advantage of such infrastructure. An example use case can be that the individual with asymmetric walking (caused by a neurological disorder), wears IoT-enabled footwear, which sends the gait parameters to the physician in a distant place in real-time. The infrastructure can also allow the physician to give feedback to the individual based on the progress.

The next problem which arises after the systems are ready for daily usage and are a part of the IoT, is how to handle the enormous amount of data coming in from these systems. Novel data processing techniques, which do not only deal with the data from one set of sensors/systems, but from multiple sensors in a smart environment, will be gaining more and more traction from researchers. This greater expanse of data will help to make better informed decisions. We also foresee that footwear-based 
systems are going to play an important role in the remote monitoring of disabled and elderly people in the future.

\subsection{Advanced Study Approaches for Footwear-Based Systems}

From a research perspective, many of the footwear-based systems have not undergone longitudinal free-living studies. Footwear are subjected to enormous amounts of wear and tear, and the electronics built into them need to be able to withstand this for a long period of time. This may be one of the reasons why Nike and some other footwear manufacturers have stopped producing their SmartShoe product lines [117]. We foresee that, in the coming years, there will be more and more longitudinal studies in free-living conditions conducted, in each of the different application scenarios.

\subsection{Affective Computing}

Affective computing is a field of technology, in which systems can determine the users' mood and emotions, based upon his or her behavior sampled through different physiological factors, and adjust a smart environment to suit their mood. There are wearable systems that monitor users joy, stress, frustration, and other moods/emotions utilizing heart rate monitoring sensors, electroencephalogram (EEG) sensors, electro dermal activity (EDA) sensors, and others [118].

From footwear-based systems perspective, there was some initial work being done with this by Lenovo with their Smartshoes [89], that display a person's mood on a small screen embedded directly on the footwear, though technical details were not available at the time of this review. Additionally, there is a Kickstarter campaign on its way to make shoes that can change their entire appearance with a smartphone application [119]. Using affective computing, it would be possible to one day change the shoes color or display to reflect the user's mood.

\section{Conclusions}

In this work we reviewed footwear-based wearable systems based on their target application. Existing footwear-based solutions from academic research as well as commercial ones in the areas of gait monitoring, plantar pressure measurement, posture and activity classification, body weight and energy expenditure estimation, biofeedback, fall risk applications, navigation, along with footwear-based energy harvesting solutions were detailed. The article also discussed sensor technology, data acquisition, signal processing techniques of different footwear-based systems along with critical discussion on their merits and demerits. Additionally, we attempted to shine a light on recent trends and future technological pathways for footwear-based solutions.

Author Contributions: NH and ES designed the research; NH conducted the literature review and segmentation based on their target application. NH, ES and MB contributed in writing the review article and proof reading. All the authors read and approved the final manuscript.

Conflicts of Interest: The authors declare no conflict of interest.

\section{References}

1. History of Footwear. Available online: http:/ /www.footwearhistory.com/ (accessed on 2 December 2015).

2. Shoes Reveal Personality Traits. Available online: http://www.scientificamerican.com/article/shoes-revealpersonality-traits/ (accessed on 2 December 2015).

3. DigiBarn Weird Stuff: Puma RS Computer Tennis Shoes (Pedometer, 1980s). Available online: http://www. digibarn.com/collections/weirdstuff/computer-tennis-shoes/ (accessed on 8 January 2016).

4. Perry, J. Gait Analysis: Normal and Pathological Function; SLACK: Thorofare, NJ, USA, 1992.

5. Crea, S.; Donati, M.; De Rossi, S.M.M.; Oddo, C.M.; Vitiello, N. A Wireless Flexible Sensorized Insole for Gait Analysis. Sensors 2014, 14, 1073-1093. [CrossRef] [PubMed]

6. GAITRite Systems-Portable Gait Analysis. Available online: http://www.gaitrite.com/ (accessed on 2 December 2015). 
7. Full Body Gait Analysis with Kinect-Microsoft Research. Available online: https://www.microsoft.com/ en-us/research/publication/full-body-gait-analysis-with-kinect/ (accessed on 7 July 2016).

8. Xu, X.; McGorry, R.W.; Chou, L.; Lin, J.; Chang, C. Accuracy of the Microsoft Kinect ${ }^{\mathrm{TM}}$ for measuring gait parameters during treadmill walking. Gait Posture 2015, 42, 145-151. [CrossRef] [PubMed]

9. Bamberg, S.J.M.; Benbasat, A.Y.; Scarborough, D.M.; Krebs, D.E.; Paradiso, J.A. Gait analysis using a shoe-integrated wireless sensor system. IEEE Trans. Inf. Technol. Biomed. 2008, 12, 413-423. [CrossRef] [PubMed]

10. Lopez-Meyer, P.; Fulk, G.D.; Sazonov, E.S. Automatic detection of temporal gait parameters in poststroke individuals. IEEE Trans. Inf. Technol. Biomed. 2011, 15, 594-601. [CrossRef] [PubMed]

11. Chen, M.; Huang, B.; Xu, Y. Intelligent shoes for abnormal gait detection. In Proceedings of the IEEE International Conference on Robotics and Automation, 2008 (ICRA 2008), Pasadena, CA, USA, 19-23 May 2008; pp. 2019-2024.

12. Mariani, B.; Jiménez, M.C.; Vingerhoets, F.J.G.; Aminian, K. On-shoe wearable sensors for gait and turning assessment of patients with Parkinson's disease. IEEE Trans. Biomed. Eng. 2013, 60, 155-158. [CrossRef] [PubMed]

13. Nsenga Leunkeu, A.; Lelard, T.; Shephard, R.J.; Doutrellot, P.-L.; Ahmaidi, S. Gait cycle and plantar pressure distribution in children with cerebral palsy: Clinically useful outcome measures for a management and rehabilitation. NeuroRehabilitation 2014, 35, 657-663. [PubMed]

14. Rampp, A.; Barth, J.; Schülein, S.; Gaßmann, K.-G.; Klucken, J.; Eskofier, B.M. Inertial sensor-based stride parameter calculation from gait sequences in geriatric patients. IEEE Trans. Biomed. Eng. 2015, 62, 1089-1097. [CrossRef] [PubMed]

15. Shop | Shimmer-Wearable Sensor Tech. Available online: http://www.shimmersensing.com/shop/ (accessed on 26 July 2016).

16. Kong, K.; Tomizuka, M. A Gait Monitoring System Based on Air Pressure Sensors Embedded in a Shoe. IEEE/ASME Trans. Mechatron. 2009, 14, 358-370. [CrossRef]

17. Liu, T.; Inoue, Y.; Shibata, K. A wearable ground reaction force sensor system and its application to the measurement of extrinsic gait variability. Sensors 2010, 10, 10240-10255. [CrossRef] [PubMed]

18. González, I.; Fontecha, J.; Hervás, R.; Bravo, J. An Ambulatory System for Gait Monitoring Based on Wireless Sensorized Insoles. Sensors 2015, 15, 16589-16613. [CrossRef] [PubMed]

19. Wu, Y.; Xu, W.; Liu, J.J.; Huang, M.-C.; Luan, S.; Lee, Y. An Energy-Efficient Adaptive Sensing Framework for Gait Monitoring Using Smart Insole. IEEE Sens. J. 2015, 15, 2335-2343. [CrossRef]

20. Ferrari, A.; Ginis, P.; Hardegger, M.; Casamassima, F.; Rocchi, L.; Chiari, L. A Mobile Kalman-Filter Based Solution for the Real-Time Estimation of Spatio-Temporal Gait Parameters. IEEE Trans. Neural Syst. Rehabil. Eng. 2016, 24, 764-773. [CrossRef] [PubMed]

21. Hegde, N.; Sazonov, E. SmartStep: A Fully Integrated, Low-Power Insole Monitor. Electronics 2014, 3 , 381-397. [CrossRef]

22. WIISEL. Available online: http:/ / www.wiisel.eu/ (accessed on 15 July 2015).

23. Huang, B.; Chen, M.; Huang, P.; Xu, Y. Gait Modeling for Human Identification. In Proceedings of the 2007 IEEE International Conference on Robotics and Automation, Roma, Italy, 10-14 April 2007; pp. 4833-4838.

24. Klucken, J.; Barth, J.; Kugler, P.; Schlachetzki, J.; Henze, T.; Marxreiter, F.; Kohl, Z.; Steidl, R.; Hornegger, J.; Eskofier, B.; et al. Unbiased and Mobile Gait Analysis Detects Motor Impairment in Parkinson's Disease. PLoS ONE 2013, 8, e56956. [CrossRef] [PubMed]

25. Barth, J.; Oberndorfer, C.; Pasluosta, C.; Schülein, S.; Gassner, H.; Reinfelder, S.; Kugler, P.; Schuldhaus, D.; Winkler, J.; Klucken, J.; et al. Stride Segmentation during Free Walk Movements Using Multi-Dimensional Subsequence Dynamic Time Warping on Inertial Sensor Data. Sensors 2015, 15, 6419-6440. [CrossRef] [PubMed]

26. Sensoria Fitness. Available online: http://www.sensoriafitness.com/ (accessed on 3 December 2015).

27. Wafai, L.; Zayegh, A.; Woulfe, J.; Aziz, S.M.; Begg, R. Identification of Foot Pathologies Based on Plantar Pressure Asymmetry. Sensors 2015, 15, 20392-20408. [CrossRef] [PubMed]

28. Mueller, M.J.; Hastings, M.; Commean, P.K.; Smith, K.E.; Pilgram, T.K.; Robertson, D.; Johnson, J. Forefoot structural predictors of plantar pressures during walking in people with diabetes and peripheral neuropathy. J. Biomech. 2003, 36, 1009-1017. [CrossRef] 
29. Plantar Pressure Assessment I Physical Therapy Journal. Available online: http://ptjournal.apta.org/ content/80/4/399 (accessed on 7 July 2016).

30. Sazonov, E.S.; Bumpus, T.; Zeigler, S.; Marocco, S. Classification of plantar pressure and heel acceleration patterns using neural networks. In Proceedings of the 2005 IEEE International Joint Conference on Neural Networks, 2005 (IJCNN 2005), Montreal, QC, Canada, 31 July-4 August 2005; Volume 5, pp. 3007-3010.

31. Morris, S.J.; Paradiso, J.A. Shoe-integrated sensor system for wireless gait analysis and real-time feedback. In Proceedings of the 24th Annual Conference and the Annual Fall Meeting of the Biomedical Engineering Society EMBS/BMES Conference (Second Joint), Houston, TX, USA, 23-26 October 2002; Volume 3, pp. 2468-2469.

32. Queen, R.M.; Haynes, B.B.; Hardaker, W.M.; Garrett, W.E. Forefoot loading during 3 athletic tasks. Am. J. Sports Med. 2007, 35, 630-636. [CrossRef] [PubMed]

33. Gioftsidou, A.; Malliou, P.; Pafis, G.; Beneka, A.; Godolias, G.; Maganaris, C.N. The effects of soccer training and timing of balance training on balance ability. Eur. J. Appl. Physiol. 2006, 96, 659-664. [CrossRef] [PubMed]

34. Mueller, M.J. Application of plantar pressure assessment in footwear and insert design. J. Orthop. Sports Phys. Ther. 1999, 29, 747-755. [CrossRef] [PubMed]

35. Begg, R.; Palaniswami, M. Computational Intelligence for Movement Sciences: Neural Networks and Other Emerging Techniques; Idea Group Inc. (IGI): Calgary, AB, Canada, 2006.

36. Zebris Medical GmbH Gait Analysis. Available online: http://www.zebris.de/english/medizin/medizinganganalyse.php\#fdm (accessed on 1 December 2015).

37. F-Scan System. Available online: https://www.tekscan.com/products-solutions/systems/f-scan-system (accessed on 1 December 2015).

38. Tan, A.M.; Fuss, F.K.; Weizman, Y.; Woudstra, Y.; Troynikov, O. Design of Low Cost Smart Insole for Real Time Measurement of Plantar Pressure. Procedia Technol. 2015, 20, 117-122. [CrossRef]

39. Shu, L.; Hua, T.; Wang, Y.; Qiao Li, Q.; Feng, D.D.; Tao, X. In-shoe plantar pressure measurement and analysis system based on fabric pressure sensing array. IEEE Trans. Inf. Technol. Biomed. 2010, 14, 767-775. [PubMed]

40. Saito, M.; Nakajima, K.; Takano, C.; Ohta, Y.; Sugimoto, C.; Ezoe, R.; Sasaki, K.; Hosaka, H.; Ifukube, T.; Ino, S.; et al. An in-shoe device to measure plantar pressure during daily human activity. Med. Eng. Phys. 2011, 33, 638-645. [CrossRef] [PubMed]

41. Pedar. Available online: http://www.novel.de/novelcontent/pedar (accessed on 1 December 2015).

42. SurroSense Rx. Available online: http:/ / orpyx.com/pages/surrosense-rx (accessed on 4 December 2015).

43. Coda, A.; Santos, D. Repeatability and Reproducibility of the F-Scan System in Healthy Children. J. Orthop. Rheumatol. Sports Med. 2015, 1, 104. [CrossRef]

44. Luo, Z.P.; Berglund, L.J.; An, K.N. Validation of F-Scan pressure sensor system: A technical note. J. Rehabil. Res. Dev. 1998, 35, 186-191. [PubMed]

45. Hamzah, H.; Osman, N.A.A.; Hasnan, N. Comparing Manufacturer's Point Calibration and Modified Calibration Setup for F-Scan Insole Sensor System: A Preliminary Assessment. In Proceedings of the 4th Kuala Lumpur International Conference on Biomedical Engineering 2008, Kuala Lumpur, Malaysia, 25-28 June 2008; Osman, N.A.A., Ibrahim, F., Abas, W.A.B.W., Rahman, H.S.A., Ting, H.-N., Eds.; Springer Berlin Heidelberg: Berlin, Germany, 2008; pp. 424-427.

46. Quesada, P.M.; Rash, G.S.; Jarboe, N. Assessment of pedar and F-Scan revisited. Clin. Biomech. (Bristol Avon) 1997, 12, S15. [CrossRef]

47. Giacomozzi, C. Appropriateness of plantar pressure measurement devices: A comparative technical assessment. Gait Posture 2010, 32, 141-144. [CrossRef] [PubMed]

48. Putti, A.B.; Arnold, G.P.; Cochrane, L.A.; Abboud, R.J. Normal pressure values and repeatability of the Emed ST4 system. Gait Posture 2008, 27, 501-505. [CrossRef] [PubMed]

49. Ferber, R.; Webber, T.; Everett, B.; Groenland, M. Validation of plantar pressure measurements for a novel in-shoe plantar sensory replacement unit. J. Diabetes Sci. Technol. 2013, 7, 1167-1175. [CrossRef] [PubMed]

50. Cazzola, D.; Trewartha, G.; Preatoni, E. Time-based calibrations of pressure sensors improve the estimation of force signals containing impulsive events. Proc. Inst. Mech. Eng. Part. P J. Sports Eng. Technol. 2014, 228, 147-151. [CrossRef]

51. Liu, T.; Inoue, Y.; Shibata, K. A wearable force plate system for the continuous measurement of triaxial ground reaction force in biomechanical applications. Meas. Sci. Technol. 2010, 21, 85804-85812. [CrossRef] 
52. Hill, J.O.; Wyatt, H.R.; Reed, G.W.; Peters, J.C. Obesity and the environment: Where do we go from here? Science 2003, 299, 853-855. [CrossRef] [PubMed]

53. Levine, J.A.; Lanningham-Foster, L.M.; McCrady, S.K.; Krizan, A.C.; Olson, L.R.; Kane, P.H.; Jensen, M.D.; Clark, M.M. Interindividual variation in posture allocation: Possible role in human obesity. Science 2005, 307, 584-586. [CrossRef] [PubMed]

54. Adult Obesity Facts. Available online: http://www.cdc.gov/obesity/data/adult.html (accessed on 2 December 2015).

55. Fulk, G.D.; Sazonov, E. Using sensors to measure activity in people with stroke. Top. Stroke Rehabil. 2011, 18, 746-757. [CrossRef] [PubMed]

56. S Health -Fitness Diet Tracker-Android Apps on Google Play. Available online: https://play.google.com/ store/apps/details?id=com.sec.android.app.shealth\&hl=en (accessed on 2 December 2015).

57. iOS 9-Health. Available online: http://www.apple.com/ios/health/ (accessed on 2 December 2015).

58. Apple Watch. Available online: http://www.apple.com/watch/ (accessed on 2 December 2015).

59. Fitbit Official Site for Activity Trackers \& More. Available online: https://www.fitbit.com/ (accessed on 2 December 2015).

60. LG G Watch R. Available online: http://www.lg.com/us/smart-watches/lg-W110-lg-watch-r (accessed on 5 August 2016).

61. Uslu, G.; Baydere, S. RAM: Real Time Activity Monitoring with feature extractive training. Expert Syst. Appl. 2015, 42, 8052-8063. [CrossRef]

62. Riou, M.-È.; Rioux, F.; Lamothe, G.; Doucet, É. Validation and Reliability of a Classification Method to Measure the Time Spent Performing Different Activities. PLoS ONE 2015, 10, e0128299. [CrossRef] [PubMed]

63. González, S.; Sedano, J.; Villar, J.R.; Corchado, E.; Herrero, Á.; Baruque, B. Features and models for human activity recognition. Neurocomputing 2015, 167, 52-60. [CrossRef]

64. Gerd Krassnig, D.T. User-friendly system for recognition of activities with an accelerometer. In Proceedings of the 2010 4th International Conference on Pervasive Computing Technologies for Healthcare, Munich, Germany, 22-25 March 2010; pp. 1-8.

65. Mathie, M.J.; Coster, A.C.F.; Lovell, N.H.; Celler, B.G. Detection of daily physical activities using a triaxial accelerometer. Med. Biol. Eng. Comput. 2003, 41, 296-301. [CrossRef] [PubMed]

66. Mathie, M.J.; Celler, B.G.; Lovell, N.H.; Coster, A.C.F. Classification of basic daily movements using a triaxial accelerometer. Med. Biol. Eng. Comput. 2004, 42, 679-687. [CrossRef] [PubMed]

67. Karantonis, D.M.; Narayanan, M.R.; Mathie, M.; Lovell, N.H.; Celler, B.G. Implementation of a Real-Time Human Movement Classifier Using a Triaxial Accelerometer for Ambulatory Monitoring. IEEE Trans. Inf. Technol. Biomed. 2006, 10, 156-167. [CrossRef] [PubMed]

68. Nishkam Ravi, N.D. Activity Recognition from Accelerometer Data. AAAI 2005, 3, 1541-1546.

69. Ferguson, T.; Rowlands, A.V.; Olds, T.; Maher, C. The validity of consumer-level, activity monitors in healthy adults worn in free-living conditions: A cross-sectional study. Int. J. Behav. Nutr. Phys. Act. 2015, 12. [CrossRef] [PubMed]

70. Lee, J.-M.; Kim, Y.; Welk, G.J. Validity of consumer-based physical activity monitors. Med. Sci. Sports Exerc. 2014, 46, 1840-1848. [CrossRef] [PubMed]

71. Spierer, D.K.; Hagins, M.; Rundle, A.; Pappas, E. A comparison of energy expenditure estimates from the Actiheart and Actical physical activity monitors during low intensity activities, walking, and jogging. Eur. J. Appl. Physiol. 2011, 111, 659-667. [CrossRef] [PubMed]

72. Sazonov, E.S.; Fulk, G.; Hill, J.; Schutz, Y.; Browning, R. Monitoring of posture allocations and activities by a shoe-based wearable sensor. IEEE Trans. Biomed. Eng. 2011, 58, 983-990. [CrossRef] [PubMed]

73. Tang, W.; Sazonov, E.S. Highly Accurate Recognition of Human Postures and Activities through Classification with Rejection. IEEE J. Biomed. Health Inform. 2014, 18, 309-315. [CrossRef] [PubMed]

74. Zhang, T.; Fulk, G.D.; Tang, W.; Sazonov, E.S. Using decision trees to measure activities in people with stroke. In Proceedings of the 2013 35th Annual International Conference of the IEEE Engineering in Medicine and Biology Society (EMBC), Osaka, Japan, 3-7 July 2013; pp. 6337-6340.

75. Zhang, T.; Lu, J.; Uswatte, G.; Taub, E.; Sazonov, E.S. Measuring gait symmetry in children with cerebral palsy using the SmartShoe. In Proceedings of the 2014 IEEE Healthcare Innovation Conference (HIC), Seattle, WA, USA, 8-10 October 2014; pp. 48-51. 
76. Sazonov, E.S.; Hegde, N.; Tang, W. Development of SmartStep: An insole-based physical activity monitor. In Proceedings of the 2013 35th Annual International Conference of the IEEE Engineering in Medicine and Biology Society (EMBC), Osaka, Japan, 3-7 July 2013; pp. 7209-7212.

77. Hegde, N.; Sazonov, E. SmartStep 2.0-A completely wireless, versatile insole monitoring system. In Proceedings of the 2015 IEEE International Conference on Bioinformatics and Biomedicine (BIBM), Washington, DC, USA, 9-12 November 2015; pp. 746-749.

78. Chen, B.; Wang, X.; Huang, Y.; Wei, K.; Wang, Q. A foot-wearable interface for locomotion mode recognition based on discrete contact force distribution. Mechatronics 2015, 32, 12-21. [CrossRef]

79. Kawsar, F.; Hasan, M.K.; Love, R.; Ahamed, S.I. A Novel Activity Detection System Using Plantar Pressure Sensors and Smartphone. In Proceedings of the 2015 IEEE 39th Annual Computer Software and Applications Conference (COMPSAC), Taichung, Taiwan, 1-5 July 2015; Volume 1, pp. 44-49.

80. Hegde, N.; Sazonov, E.S.; Melanson, E. Development of a Real Time Activity Monitoring Android Application Utilizing SmartStep. In Proceedings of the 2016 38th Annual International Conference of the IEEE Engineering in Medicine and Biology Society (EMBC), Orlando, FL, USA, 16-20 August 2016.

81. Sazonov, E.; Hegde, N.; Browning, R.C.; Melanson, E.L.; Sazonova, N.A. Posture and activity recognition and energy expenditure estimation in a wearable platform. IEEE J. Biomed. Health Inform. 2015, 19, 1339-1346. [CrossRef] [PubMed]

82. Fulk, G.D.; Edgar, S.R.; Bierwirth, R.; Hart, P.; Lopez-Meyer, P.; Sazonov, E. Identifying activity levels and steps of people with stroke using a novel shoe-based sensor. J. Neurol. Phys. Ther. JNPT 2012, 36, 100-107. [CrossRef] [PubMed]

83. Maurer, U.; Smailagic, A.; Siewiorek, D.P.; Deisher, M. Activity recognition and monitoring using multiple sensors on different body positions. In Proceedings of the International Workshop on Wearable and Implantable Body Sensor Networks (BSN'06), Cambridge, MA, USA, 3-5 April 2006; p. 116.

84. Edgar, S.R.; Fulk, G.D.; Sazonov, E.S. Recognition of household and athletic activities using SmartShoe. In Proceedings of the 2012 Annual International Conference of the IEEE Engineering in Medicine and Biology Society, San Diego, CA, USA, 28 August-1 September 2012; pp. 6382-6385.

85. Benocci, M.; Rocchi, L.; Farella, E.; Chiari, L.; Benini, L. A wireless system for gait and posture analysis based on pressure insoles and Inertial Measurement Units. In Proceedings of the 2009 3rd International Conference on Pervasive Computing Technologies for Healthcare, London, UK, 1-3 April 2009; pp. 1-6.

86. Sazonova, N.; Browning, R.C.; Sazonov, E. Accurate prediction of energy expenditure using a shoe-based activity monitor. Med. Sci. Sports Exerc. 2011, 43, 1312-1321. [CrossRef] [PubMed]

87. Dannecker, K.L.; Sazonova, N.A.; Melanson, E.L.; Sazonov, E.S.; Browning, R.C. A comparison of energy expenditure estimation of several physical activity monitors. Med. Sci. Sports Exerc. 2013, 45, 2105-2112. [CrossRef] [PubMed]

88. Lechal. Available online: http://lechal.com/insoles.html (accessed on 3 December 2015).

89. Smart Shoe. Available online: https://us.vibram.com/article-smart-shoe.html (accessed on 3 December 2015).

90. Gjoreski, H.; Kaluža, B.; Gams, M.; Milić, R.; Luštrek, M. Context-based ensemble method for human energy expenditure estimation. Appl. Soft Comput. 2015, 37, 960-970. [CrossRef]

91. Villanueva, E.V. The validity of self-reported weight in US adults: A population based cross-sectional study. BMC Public Health 2001, 1, 11. [CrossRef] [PubMed]

92. Sazonova, N.A.; Browning, R.; Sazonov, E.S. Prediction of Bodyweight and Energy Expenditure Using Point Pressure and Foot Acceleration Measurements. Open Biomed. Eng. J. 2011, 5, 110-115. [CrossRef] [PubMed]

93. Hellstrom, P.; Folke, M.; Ekström, M. Wearable Weight Estimation System. Procedia Comput. Sci. 2015, 64, 146-152. [CrossRef]

94. Khoo, I.-H.; Marayong, P.; Krishnan, V.; Balagtas, M.N.; Rojas, O. Design of a biofeedback device for gait rehabilitation in post-stroke patients. In Proceedings of the 2015 IEEE 58th International Midwest Symposium on Circuits and Systems (MWSCAS), Fort Collins, CO, USA, 2-5 August 2015; pp. 1-4.

95. Hegde, N.; Fulk, G.D.; Sazonov, E.S. Development of the RT-GAIT, a Real-Time feedback device to improve Gait of individuals with stroke. In Proceedings of the 2015 37th Annual International Conference of the IEEE Engineering in Medicine and Biology Society (EMBC), Milan, Italy, 25-29 August 2015; pp. 5724-5727. 
96. Yang, L.; Dyer, P.S.; Carson, R.J.; Webster, J.B.; Bo Foreman, K.; Bamberg, S.J.M. Utilization of a lower extremity ambulatory feedback system to reduce gait asymmetry in transtibial amputation gait. Gait Posture 2012, 36, 631-634. [CrossRef] [PubMed]

97. Donovan, L.; Feger, M.A.; Hart, J.M.; Saliba, S.; Park, J.; Hertel, J. Effects of an auditory biofeedback device on plantar pressure in patients with chronic ankle instability. Gait Posture 2016, 44, 29-36. [CrossRef] [PubMed]

98. Aging Statistics. Available online: http://www.aoa.acl.gov/Aging_Statistics/index.aspx (accessed on 7 May 2015).

99. NIHSeniorHealth: Falls and Older Adults—Causes and Risk Factors. Available online: http://nihseniorhealth. gov/falls/causesandriskfactors/01.html (accessed on 2 December 2015).

100. Schwenk, M.; Hauer, K.; Zieschang, T.; Englert, S.; Mohler, J.; Najafi, B. Sensor-derived physical activity parameters can predict future falls in people with dementia. Gerontology 2014, 60, 483-492. [CrossRef] [PubMed]

101. Doukas, C.; Maglogiannis, I. Advanced patient or elder fall detection based on movement and sound data. In Proceedings of the 200 Second International Conference on Pervasive Computing Technologies for Healthcare, Tampere, Finland, 30 January-1 February 2008; pp. 103-107.

102. Ayena, J.C.; Chapwouo, T.L.D.; Otis, M.J.-D.; Menelas, B.A.J. An efficient home-based risk of falling assessment test based on Smartphone and instrumented insole. In Proceedings of the 2015 IEEE International Symposium on Medical Measurements and Applications (MeMeA), Turin, Italy, 7-9 May 2015; pp. 416-421.

103. Sim, S.Y.; Jeon, H.S.; Chung, G.S.; Kim, S.K.; Kwon, S.J.; Lee, W.K.; Park, K.S. Fall detection algorithm for the elderly using acceleration sensors on the shoes. In Proceedings of the 2011 Annual International Conference of the IEEE Engineering in Medicine and Biology Society (EMBC), Boston, MA, USA, 30 August-3 September 2011; pp. 4935-4938.

104. Majumder, A.J.A.; Zerin, I.; Uddin, M.; Ahamed, S.I.; Smith, R.O. SmartPrediction: A Real-time Smartphone-based Fall Risk Prediction and Prevention System. In Proceedings of the 2013 Research in Adaptive and Convergent Systems RACS '13; ACM: New York, NY, USA, 2013; pp. 434-439.

105. Documents I WIISEL. Available online: http://www.wiisel.eu/?q=content/documents (accessed on 20 June 2016).

106. Otis, M.J.-D.; Menelas, B.J. Toward an augmented shoe for preventing falls related to physical conditions of the soil. In Proceedings of the 2012 IEEE International Conference on Systems, Man, and Cybernetics (SMC), Seoul, Korea, 14-17 October 2012; pp. 3281-3285.

107. Schirmer, M.; Hartmann, J.; Bertel, S.; Echtler, F. Shoe Me the Way: A Shoe-Based Tactile Interface for Eyes-Free Urban Navigation. In Proceedings of the 17th International Conference on Human-Computer Interaction with Mobile Devices and Services MobileHCI '15; ACM: New York, NY, USA, 2015; pp. 327-336.

108. Bebek, O.; Suster, M.A.; Rajgopal, S.; Fu, M.J.; Huang, X.; Çavuşoğlu, M.C.; Young, D.J.; Mehregany, M.; van den Bogert, A.J.; Mastrangelo, C.H. Personal Navigation via High-Resolution Gait-Corrected Inertial Measurement Units. IEEE Trans. Instrum. Meas. 2010, 59, 3018-3027. [CrossRef]

109. Castaneda, N.; Lamy-Perbal, S. An improved shoe-mounted inertial navigation system. In Proceedings of the 2010 International Conference on Indoor Positioning and Indoor Navigation (IPIN), Zurich, Switzerland, 15-17 September 2010; pp. 1-6.

110. Foxlin, E. Pedestrian tracking with shoe-mounted inertial sensors. IEEE Comput. Graph. Appl. 2005, 25, 38-46. [CrossRef] [PubMed]

111. Shenck, N.S.; Paradiso, J.A. Energy scavenging with shoe-mounted piezoelectrics. IEEE Micro 2001, $21,30-42$. [CrossRef]

112. Orecchini, G.; Tentzeris, M.M.; Yang, L.; Roselli, L. Smart Shoe: An autonomous inkjet-printed RFID system scavenging walking energy. In Proceedings of the 2011 IEEE International Symposium on Antennas and Propagation (APSURSI), Spokane, WA, USA, 3-8 July 2011; pp. 1417-1420.

113. Zhao, J.; You, Z. A shoe-embedded piezoelectric energy harvester for wearable sensors. Sensors 2014, 14, 12497-12510. [CrossRef] [PubMed]

114. Kymissis, J.; Kendall, C.; Paradiso, J.; Gershenfeld, N. Parasitic power harvesting in shoes. In Proceedings of the Second International Symposium on Wearable Computers, 1998 Digest of Papers, Pittsburgh, PA, USA, 19-20 October 1998; pp. 132-139. 
115. Meier, R.; Kelly, N.; Almog, O.; Chiang, P. A piezoelectric energy-harvesting shoe system for podiatric sensing. In Proceedings of the 2014 36th Annual International Conference of the IEEE Engineering in Medicine and Biology Society (EMBC), Chicago, IL, USA, 26-30 August 2014; pp. 622-625.

116. Internet of Things. Available online: https://en.wikipedia.org/wiki/Internet_of_things (accessed on 3 August 2016).

117. The Rise and Fall of the Smart Shoe-and Why They Could Be on the Way Back. Available online: http://www.wareable.com/running/smart-shoes-875 (accessed on 5 December 2015).

118. MIT Media Lab: Affective Computing Group. Available online: http://affect.media.mit.edu/projects.php (accessed on 26 July 2016).

119. ShiftWear: Customize Your Kicks. Available online: https://www.indiegogo.com/projects/shiftwearcustomize-your-kicks/\#/story (accessed on 5 December 2015).

(C) 2016 by the authors; licensee MDPI, Basel, Switzerland. This article is an open access article distributed under the terms and conditions of the Creative Commons Attribution (CC-BY) license (http://creativecommons.org/licenses/by/4.0/). 